\title{
ABUSE OF PROCEDURAL RIGHTS IN POLISH AND EUROPEAN CIVIL PROCEDURE LAW AND THE NOTION OF PRIVATE AND PUBLIC INTEREST
}

\author{
Katarzyna Gajda - Roszczynialska \\ Ph.D., Ass. Professor, Chair of Civil Procedure, University \\ of Silesia in Katowice, judge \\ in the District Court for Krakow - Krowodrza \\ (Krakow, Poland)
}

https://doi.org/10.33327/AJEE-18-2.3-a000013

Summary: 1. Introduction. - 2. Legal Interest and Abuse of Civil Procedural Rights. - 3. Abuse of Right in the Polish Civil Procedure. - 4. Abuse of Right in the European Civil Procedure. - 4.1. Abuse of the Right to File an Action and the Right of Defense in European Procedural Right. - 4.2. Abuse of Right under Regulation of Council (EC) 1346/2000 of 29 May 2000 on insolvency proceedings and regulation No. 2015/848 of 20 May 2015. - 4.3. Abuse of Procedural Rights under Regulation of Council (EC) 44/2001 of 22 December 2000 on Jurisdiction and Recognition of Court Decisions and Enforcement in Civil and Commercial Cases and Regulation of European Parliament and Council (EU) No. 1215/2012 of 12 December 2012 on Jurisdiction and Recognition of Court Decisions and Enforcement in Civil and Commercial Cases. 5. - Concluding Remarks

The article discusses the abuse of procedural rights in Polish and European civil procedure law and the notion of private and public interest. The issue of abuse of procedural rights is a category of applying the law. At the current stage of development there is no simple transposition of the issue of legal interest on the institution of abuse of procedural right; undeniably, the lack of current and real interest, with the assumption of fulfillment of other prerequisites, may be contemplated in categories of abuse of right by the court under ius dicere. In the Polish law it is not sufficient to analyse this phenomenon solely in the sphere of procedural locus standi and there shall be the interest in taking a specific step. There also shall be the awareness of the party taking the step as to its inadmissibility and intention to harm the other party, as e.g. in case of fictitious actions. In the European area it is additionally necessary to create methodology and general approach to abuse of right in European civil proceedings and finding compromising approach towards understanding of the notion of the interest in Roman and Germanic law systems. Because application and development of the law due to lack of procedural fairness and good faith is rather difficult to verify and to define, the advantage of adopting admissibility of a separate international institution of abuse of procedural right would lie in the possibility of applying a universal 
approach towards abuse of procedural right in all member states. Thiswould mean that each court of the member state would apply the same standard of the test. Finally, the alternative use of exclusively national concepts of abuse of procedural right cannot be continued. It can be assumed that confirmation of the existence of the abuse of European procedural right in a given case would require existence of objective and subjective factors.

Key words: abuse of procedural rights, civil procedure law, the notion of private interest, the notion public interest, European civil procedural law.

\section{INTRODUCTION}

The issue of abuse of procedural rights is a category of applying the law. ${ }^{1}$ In this way it is naturally connected with judicial power, as the notion, in fact, is created by it. Judicial power is authoritarian ius dicere, namely the power to announce what law applies in a given case in contrast to dare. ${ }^{2}$ The notion of procedural abuse of rights undoubtedly was created as a result of court practice, which resulted in the necessity to correct the procedural steps of the parties and participants in the proceedings within the frames of public civil procedure application of the principle of the rule of law on the basis of such principles as good faith, morality, honesty, justice, security and stability. It is based on assumption that despite formally correct application of law the objective goal of the legal norm is not reached. This is why it is necessary to introduce a specific measure aiming at implementation of basic procedural standards and principles, also with respect to European civil procedural law according to the agreed standard. The said is connected with the existence of a certain conflict in the frames of law application. The application within the frames of judicial power of the correcting mechanism in the form of abuse of rights should reduce the tension between strict law observance (lex), and the goal and spirit of the statute (ius). ${ }^{3}$ Such application occurs within the frames of ius dicere. The natural sphere to analyse the principle prohibiting the abuse of rights involves private law, however, the prohibition of abuse of rights is also discussed in the area of national civil proceedings, in particular, in the scope of Polish civil procedure as well as European civil procedure law. Lack of statutory definitions requires a detailed description of this phenomenon. Undoubtedly, what is a crucial and necessary element is the determination that the procedural 'tools' were used contrary to the purpose they were created for. In practice it refers to procedural steps of the parties and participants which are in fact permitted, at the level of procedural norms - neutral, but from the perspective of the goal of the proceedings and protection standards, they must be perceived negatively as hampering the course of the proceedings.

1 See T Ereciński, 'Nadużycie praw procesowych w postępowaniu cywilnym. Tezy i wstępne propozycje do dyskusji' in P. Grzegorczyk, M. Walasik, F. Zedler (eds), Nadużycie prawa procesowego cywilnego (Wolters Kluwer 2019) 11.

2 AX Fellmeth, M Horwitz, Guide to Latin in International Law (OUP 2011) 101 et seq.

3 Compare A Lenaerts, 'The general Principle of the Prohibition of Abuse of Rights. A Critical Position on Its Role in a Codified European Contract Law' (2010) 6 European Review of Private Law1121; L Baudenbacher, 'Überlegungen zum Verbot des Rechtsmissbrauchs im Europäischen Gemeinschaftsrecht' (2008) 205 Zeitschrift für Rechtsvergleichung, internationales Privatrecht und Europarecht; V Karayannis, L'abus de droits découlant de l'ordre juridique communautaire. A propos de l'arrêt C-367/96 Alexandros Kefalas e.a./Elliniko Dimosio (État hellénique) (CDE 1999) 521-522; A Kjellgren, 'On the Border of Abuse: The Jurisprudence of the European Court of Justice on Circumvention, Fraud and Other Misuses of Community Law' (2000) 179 European Business Law Review. 
It can be said that the concept of abuse to a significant extent is based on the assumption of abuse of procedural rights claiming at the same time that there is necessity of observing the principles of fair and loyal proceedings both by the court and the parties, which constitutes in the procedural area the transposition of the substantive concept of bona fide. There are also opinions sanctioning the abuse in the categories of public service of the administration of justice fulfilling a servient role with respect to implementation of the individual rights of the Europeans. ${ }^{4}$ The said is connected with two concepts appearing in the legal comparative perspective. ${ }^{5}$ The first one - used mostly inter alia in Belgium, ${ }^{6}$ Holland, ${ }^{7}$ Luxembourg, France ${ }^{8}$ or Italy ${ }^{9}-$ is based on the existence of individual rights of citizens reflected also in certain procedural rights such as e.g. the right to initiate action, to defence, to lodge an appeal, to enforce the court decision. The implementation of such rights is not unlimited, though. Its freedom ends where the abuse starts. The abuse of procedural rights during procedural steps most often takes place where procedural rights are implemented in an incorrect and grossly defective way. The abuse of procedural rights is implied exclusively by non-standard and defective at the same time exercise of a procedural right, connected with the failure to understand its gist. ${ }^{10}$ The second, broader approach - existing mainly in Germany or ${ }^{11}$ Spain $^{12}$ - is not based on individual rights of people but on the obligation to take procedural steps honestly with the obligation to conduct the proceedings in a loyal and honest way. ${ }^{13}$ Pursuant to this concept all the parties to civil proceedings active in the proceedings are obliged to take all procedural steps in accordance with the principle of loyalty and good faith as in the lack of those two elements it is not justice. ${ }^{14}$ The obligation to proceed in an honest and loyal way creates a specific right to prevent serious and detrimental deviation from commonly accepted procedural norms. ${ }^{15}$ The obligation of

4 M Storme, 'Foreword' in M. Taruffo (ed), Abuse of procedural rights: comparative standards of procedural fairness, (Haga-Londyn-Boston 1999) XI.

5 see J Normand, 'Final Report. The two approaches to abuse of procedural rights' in M. Taruffo (ed), Abuse of procedural rights: comparative standards of procedural fairness (Haga-Londyn-Boston 1999) 237.

6 P Taelman, 'Abuse of procedural rights: Regional report for Belgium - The Netherlands' in M Taruffo (ed), Abuse of procedural rights: comparative standards of procedural fairness, (Kluwer Law International 1999125 et seq.

7 Taelman (n 6) 125 et seq.

8 A Donti, 'Abuse of procedural rights: Regional report for Italy and France' in M Taruffo (ed), Abuse of procedural rights: comparative standards of procedural fairness, (Kluwer Law International $1999 \mathrm{p} 125 \mathrm{et}$ seq; M Klöpfer, Missbrauch im Europäischen Zivilverfahrensrecht (Mohr Siebeck 2016) 192-194.

9 Donti (n 8) 125 et seq.

10 see Normand (n 5) 237-239.

11 See Klöpfer (n 8) 187-191; B Hess, 'Abuse of procedural rights in Germany i Austria' in M Taruffo (ed), Abuse of procedural rights: comparative standards of procedural fairness (Kluwer Law International 1999) 151 et seq.

12 FR Mendez, 'Abuse of procedural rights? Spain and Portugal' in M Taruffo (ed), Abuse of procedural rights: comparative standards of procedural fairness (Kluwer Law International 1999)181 et seq.

13 This approach exists also in the USA (see GC. Hazard, 'Abuse of procedural rights: Regional Report for United States' in M Taruffo (ed), Abuse of procedural rights: comparative standards of procedural fairness (Kluwer Law International 1999) 43 et seq.), Japan (see J Taniguchi, Abuse of procedural rights: A japanese perspective' in M Taruffo (ed), Abuse of procedural rights: comparative standards of procedural fairness (Kluwer Law International 1999) 215 et seq.) or South America (see ED Oteiza, 'Abuse of procedural rights in Latin America' in M Taruffo (ed), Abuse of procedural rights: comparative standards of procedural fairness (Kluwer Law International 1999) 191 et seq.

14 see Normand (n 5) 240-241.

15 See Hazard (n 13) 43 et seq. 
fair proceedings is imposed not only on the petitioner or the defendant but clearly on the adjudicating body. All (both the parties and the court) are obliged to act in good faith, and generally to respect fair and honest proceedings. Both concepts to a smaller or greater degree are a reference point for the analysis of abuse of procedural rights in both European and national area.

In the literature it is underlined that from the legal comparative perspective we are approaching the day when the abuse of procedural rights can be discussed with the use of common language. ${ }^{16}$ The broadest notion in the analyzed scope involves the abuse of civil procedural right which includes both the abuse of the right to the proceedings and the abuse by taking procedural steps during the proceedings. The abuse of right to civil proceedings means the abuse of right to be given legal protection by the court in civil proceedings. The abuse may be committed by the petitioner and then it includes the abuse of the right of action in European civil proceedings as well as by the defendant and then it includes the abuse of the right of defence in European civil procedural law.

The abuse of the right to initiate action in the civil procedural law takes place e.g. in a situation where the petitioner starts the action being aware that he lacks interest. It takes place especially when the action is started without any legal or factual grounds and the allegation of abuse is completely groundless, the action is started exclusively to obtain advice from court (without any other reason) or a fictitious action is started. ${ }^{17}$ With respect to abuse of right to initiate action other situations include the initiation of the action with the breach of res iudicata principle, while the others - to settle the case despite the lapse of limitation period. ${ }^{18}$ Those comments may to a smaller or greater degree refer to abuse of the right of defence. In particular, completely unjustified or clearly groundless defence may be deemed abuse of procedural rights. The abuse of the right of defence may consist in starting defence in an obvious way without factual or legal conditions required by the law. ${ }^{19}$

Each evaluation should depend on a specific case and should be made within the frames of judicial ius dicere. ${ }^{20}$ From the subjective point of view this evaluation depends ad casu on the intention of the person taking the procedural step. This definitional element creates an obvious problem in creating general definition of the abuse of civil procedural right. The abuse should result from a fraud or such gross misconduct (error) that could be deemed equivalent to a fraud. The subjective feature of the abuse in civil procedural law should include the fact that an ordinary mistake or negligence is not enough to create an abuse.

In the individual aspect in the European procedural civil law we may distinguish adversarial abuse, i.e. made by one party to the other party and adjudicatory abuse i.e. made by the court to the parties. ${ }^{21}$ The literature underlines, however, that the

16 See Normand (n 5) 242.

17 M Taruffo, 'General Report: Abuse of Procedural Rights: Comparative Standards of Procedural Fairness' in M Taruffo (ed), Abuse of procedural rights: comparative standards of procedural fairness (Kluwer Law International 1999) 15.

Taruffo (n 17) 16.

19 Taruffo (n 17) 16.

20 Taruffo (n 17) 21-22.

21 See R Fentiman, 'Abuse of procedural rights: The position of English Law' in M Taruffo (ed), Abuse of procedural rights: comparative standards of procedural fairness (Kluwer Law International 1999) 43 et seq. 
concept of abuse of rights by the court is of symbolic significance, as the possibility of committing an abuse by the court is scarce. In this situation the notion of abuse of powers is undoubtedly more apt. ${ }^{22}$

\section{LEGAL INTEREST AND ABUSE OF CIVIL PROCEDURAL RIGHTS}

As a consequence, one of the fundamental questions asked as a result of discussion about the abuse of right in the Polish and European civil proceedings is as follows: is the existence of the legal interest in gaining legal protection important in the abuse of procedural rights? ${ }^{23}$ The answer to this question is connected with the adopted concept of the legal interest. It should be underlined that in this scope there are various opinions in various legal orders. For example, in France there is a general principle saying that having legal interest is a prerequisite for demanding legal protection in court (in accordance with the established maxim pas d'interet, pas d'action). ${ }^{24}$ The interest as the general prerequisite for seeking court protections is indicated in s. 31 of the French CPC, whereby the provision says that is should be legitimate. Wherefore, in the light of the fact that the notion of legitimate interest in the context of legitimacy of the enforced claim raises various doubts, it is postulated that instead of using the word legitimate we should use the notion of legal interest. ${ }^{25}$ The interest must be individual and valid, it is the prerequisite for admissibility and belongs to the substantive prerequisites for settling the case. Wherefore, the prerequisite for the interest does not refer to situations in which prosecutor operates, which results from the fact that the prosecutor does not act in the private interest (to which the requirement refers) but in the public interest. Similarly in Italy in S. 100 of Codice di procedura civile - Italian $\mathrm{CPC}$, the interest becomes a prerequisite for admissibility of action. Analogously, the prerequisite for the interest does not refer to situations in which prosecutor operates, which results from the fact that the prosecutor does not act in the private interest (to which the requirement refers to) but in the public interest. ${ }^{26}$ In Germany there is no provision which would deem legal interest as a prerequisite for admissibility of action. In Germany the view prevails that the need for legal protection is a general prerequisite for admissibility of action in a case (Rechtsschutzbedürfnis). This prerequisite does not refer to bodies acting in the public interest (administrative bodies or prosecutor). ${ }^{27}$ Analogously in Austria there is a notion of general interest in gaining legal protection (Rechtsschutzinteresse), defined also according to the German model as the need for legal protection (Rechtsschutzbedürfnis), where legitimization (an abstract notion) is distinguished from the person having a specific right. ${ }^{28}$ This analysis shows that the interest is deemed a prerequisite for granting legal protection in the aspect of initiating action or lodging an appellate measure.

22 see Normand (n 5) 242.

23 As in: Ereciński (n 1) P. Grzegorczyk, M. Walasik, F. Zedler 14.

24 P Rylski, K Weitz, 'Interet, interesse ad impugnare, Beschwer, aggrievance' in K SzczepanowskaKozłowska (ed), Oblicza prawa cywilnego. Księga jubileuszowa dedykowana Prof. Janowi Błeszyńskiemu (Wolters Kluwer 2013) 589 and the literature quoted therein.

25 Rylski, Weitz (n 24) 589 and the literature quoted therein.

26 Rylski, Weitz (n 24) 597 and the literature quoted therein.

27 Rylski, Weitz (n 24) 601 and the literature quoted therein.

28 Rylski, Weitz (n 24) 605 and the literature quoted therein. 
The Polish literature lacks deep connection of the issue of legal interest with the abuse of law. The comments appearing in the literature are of auxiliary and enigmatic nature. In the literature the initiation of an action without legitimate legal interest is deemed abuse of procedural rights. ${ }^{29}$ It is indicated that this results from the fact that application of a legal procedural norm which in theory is correct but is not proper, just and fair. ${ }^{30}$ Simultaneously, an opposing viewpoint is presented indicating that the view is wrong, firstly due to the fact that the civil procedure code is undeniably constructed to combat any abuses of procedural right, however the admissibility of prevention of effectiveness of procedural steps of the parties may take place only in the way defined in procedural provisions and the procedure law does not offer an obvious remedy for filing a clearly groundless petition (application) or filing it for a different purpose than obtaining legal protection. ${ }^{31}$ Secondly, the construction of ignoring the petitions (applications) initiating the fictitious action contradicts clearly the primate principle of administration of justice in the form of the right of recourse to court. ${ }^{32}$ This view does not deserve being taken into consideration.

The suggested concept assumes the necessity of existence of a real and valid interest in the objective and subjective aspect with respect to essential procedural steps. The judicial power is entrusted in the context of existence of the interest with the evaluation of adequacy of a specific procedural step taken with respect to its purpose, taking into account both objective and subjective criteria. If it is determined that the specific procedural step deviates from its purpose and has cumulatively a negative impact on the sphere of other entities, then it is an abuse of procedural rights. The abuse may be detrimental not only to the parties and participants (private interest, good faith, morality, honesty, justice) but also to the administration of justice (security and stability). ${ }^{33}$ The criteria of abuse of procedural rights assume within the judicial power the subjective evaluation (specific degree of guilt) and objective evaluation (comparing with the model in the form of reasonable behaviour). ${ }^{34}$

\section{ABUSE OF RIGHT IN THE POLISH CIVIL PROCEDURE}

The discussion about the abuse of right has been pending since the beginning of 20th century. In the Polish civil procedure science K. Piasecki wrote in the 60 s of the 20th

29 K Piasecki, 'Nadużywanie praw procesowych przez strony' (1960) 11 Palestra 28; T Cytowski, 'Procesowe ndużycie prawa' [2005] Przegląd Sądowy 83; H Dolecki, 'Nadużycie prawa do sądu' in J. Góral, R. Hausner, J. Trzciński (eds), Sądownictwo administracyjne gwarantem wolności i praw obywatelskich 1980 - 2005(Nacz. Sąd Administracyjny 2005) 137; K Knoppek, 'Wstęp do badań nad fikcyjnym procesem cywilnym' in P Grzegorczyk, K Knoppek, M Walasik (eds), Księga Jubileuszowa dedykowana Profesorowi Feliksowi Zedlerowi (Wolters Kluwer 2012) 189 - 205.

30 As in A Stępkowski, 'Nadużycie prawa, a rozwój prawa' in H. Izdebski, A. Stępkowski (eds), Nadużycie prawa (Liber 2003) 49.

31 Knoppek (n 29) 205; J Misztal - Konecka, 'Czy wniesienie pozwu w sprawie cywilnej przeciwko sędziemu może stanowić nadużycie prawa procesowego- zarys problemu’ in P. Grzegorczyk, M. M Walasik, F. Zedler (eds), Nadużycie prawa procesowego cywilnego (Wolters Kluwer 2019) 83. As in: Stępkowski (n 31).

32 Misztal - Konecka (n 31) 84, M Plebanek, Nadużycie prawa procesowego (Wolters Kluwer 2012)103 114 together with the quoted literature.

33 As in Ereciński (n 1) 16-17.

34 K Gajda - Roszczynialska, 'Nadużycie prawa w europejskim prawie procesowym cywilnym' in P Grzegorczyk, M. Walasik, F. Zedler (eds), Nadużycie prawa procesowego cywilnego (Wolters Kluwer 2019) $490-620$. 
century about the procedural steps of the parties taken contrary to the principles of social coexistence. ${ }^{35}$ The first attempts of incorporating into Civil Procedure Code the point of reference for the construction of abuse of procedural rights were made in 1955 . In s. 8 of the bill of Civil Procedure Code of the Republic of Poland it was provided that 'procedural steps shall be taken by the participants according to the principles of social coexistence. ${ }^{36}$ In the next bill dated 1960 the idea of linking procedural steps with the principle of social coexistence was resumed, changing slightly the wording of S. 4 as follows: 'procedural steps taken by the parties to and participants in the proceedings shall not contradict the principles of social coexistence. ${ }^{37}$ The breach of this prohibition was sanctioned by the obligation to pay the court fees. Another Bill of the Civil Procedure Code which was passed did not contain the obligation of compliance of procedural steps with the principles of social coexistence (S. $3 \$ 1 \mathrm{CPC}$ ), only the sanction of reimbursing the court fees was left if the party was guilty of unconscientious or clearly unreasonable conduct (S. 103 CPC). As a consequence, it is assumed that by 2012, namely till the change of S. 3 CPC became effective ${ }^{38}$ - the prohibition of abuse of procedural rights was derived from the general principles of law. ${ }^{39}$ The literature shows that this status quo led to the situation that the judges had no effective and operative tools enabling adequate reaction to such a situation, which was not changed by S. 103 of CPC. ${ }^{40}$ The only conclusive inference which was derived from the said situation was that the abuse of process may take place only within the frames of the process, within the public and legal procedural relation between the petitioner - defendant and the court, so in general terms upon instituting the proceedings and ending upon its termination. ${ }^{41}$ In this legal status before 2012 the courts had referred to abuse of procedural rights rather prudently. For example, in the judgment of 16 July $2009^{42}$ the Supreme Court, examining the validity of rejecting the motion of the party for adjournment of a trial stated that such a motion may constitute abuse of procedural rights if it insults the opposing party. Subsequently, the Supreme Court in the order of 20 November $2009^{43}$ refusing to adopt a resolution, claimed that the civil process ensures protection of the person only under specific social principles; consequently, public resources cannot be used for unnecessary purposes and abuse of rights. The interest of a person which pursuant to common view is so minor that does not justify involvement of the court shall not be protected. In the appeal the value of claim amounted to $4,71 \mathrm{zk}$. This amount is grossly small and the real costs of proceedings to be borne by the society - high. In such circumstances involving the Supreme Court in settling the said legal issue would be a misunderstanding. This decision is crucial not only from the point of view of abuse of procedural rights but also in the context of linking the institution of abuse of procedural rights to the existence

35 Piasecki (n 29) $20-28$.

36 Projekt kodeksu postępowania cywilnego Polskiej Rzeczpospolitej Ludowej (Warszawa 1955) 6.

37 Projekt kodeksu postępowania cywilnego Polskiej Rzeczpospolitej Ludowej (Warszawa 1960).

38 Sec. 1(1) of the Act of 16 September 2011 on amending the law Civil Procedure Code and certain other acts (Dz. U. no. 233, item 1381).

39 As in: J Gudowski, 'Nadużycie prawa procesowego w postępowaniu rozpoznawczym (in ampliore contextu). Tezy i wstępne propozycje do dyskusji’ in P Grzegorczyk, M Walasik, F Zedler (eds), Nadużycie prawa procesowego cywilnego (Wolters Kluwer 2019,) 33 - 34.

40 As in: Gudowski (n 39) 34.

41 As in: Gudowski (n 39) 34.

42 Case file no.: I CSK 30/09.

43 Case file no. III CZP 90/09 Biul. SN 2009 no. 11, www.sn.pl, Legalis. 
of the interest. It can indirectly be derived from the decision that lack of real and valid interest may mean that the undertaken procedural step abusing the procedural rights may not lead to intended legal effects.

In the context of the abuse of procedural right in the court proceedings the order of the Supreme Court - Civil Chamber of 26 July $1978{ }^{44}$ is quoted, in which it was asserted that the request for recognition of the foreign divorce judgment by the spouse who was intentionally misrepresenting to the other spouse the purpose and legal effects of such a divorce encouraged the latter to stop defending the interests of the minor children of the parties in the divorce proceedings and to have no objections to adjudication of the divorce would contradict the principles of social coexistence in the People's Republic of Poland. The request for making the foreign judgment, awarded in such circumstances, effective in Poland should be deemed an abuse by the spouse demanding the recognition, of the right held by such a spouse (S. 5 of the CC) so on this basis the request for recognition would be rejected.

An indirect reference to the construction of the abuse of procedural rights was made also by the Supreme Court in the order of 30 July $1965{ }^{45}$ with respect to the division of the amount obtained through enforcement claiming that if strict observance of the division system under S. 1026(1) of the CPC with respect to maintenance is to be applied, then it would lead to such a situation that the monthly amount resulting from the division would not satisfy the basic needs of some creditors, and it would cover the needs of the other ones four times - then the demand for such a type of division, being grossly in conflict with the justified interest of one or a few creditors and simultaneously inconsistent with the principles of social coexistence in People's Republic of Poland, could not be legally protected. One cannot distinguish between the current and outstanding maintenance favouring the current one.

The change in this scope took place together with the amendment to s. 3 CPC which since 3 May 2012 has had the following wording: 'The parties to and participants in the proceedings shall carry out the procedural steps in accordance with good practice, provide explanations as to the facts of the case truthfully and without concealing anything and file evidence. The applicable construction introduces a reference point for the mechanism of abuse of procedural rights. ${ }^{46}$ It can be said that since 3 May $2012{ }^{47}$ the postulate of fair process addressed to the parties has received the normative status. Currently in S. 3 $\mathrm{CPC}$ the obligation of fair process was formulated as the obligation of the parties to and participants in the proceedings to take procedural steps pursuant to good practice, which includes also non-abuse of procedural rights. This obligation defined in the literature as 'the procedural burden' was not linked to any general sanction however; if the party fails to meet it, the party may expect an unfavourable result of the proceedings, as the court may take into account such a situation when taking the procedural decisions.

$44 \quad$ Case file no.: II CR 248/78, PiP 1981 no. 1, p. 141, Legalis

45 Case file no.: II CZ 68/65, OSNCP 1966 no. 6, item 95, Legalis.

46 See the grounds for the bill of the Act on Amendment to the Law - Civil Procedure Code and Certain Other Acts (Sejm Paper 4332). See also K Weitz, 'System koncentracji materiału procesowego według projektu zmian Kodeksu postępowaniacywilnego'in K Markiewicz (ed), Reforma postępowania cywilnego w świetle projektów Komisji Kodyfikacyjnej (CH Beck 2011) 11.

47 Namely from the moment the Act of 16 September 2011 on Amendment to the Law - Civil Procedure Code and Certain Other Acts (Dz.U. No. 233, Item 1381 came into force. 
In this context we should quote the first and so far the longest opinion of the Supreme Court in the context of abuse of rights, i.e. resolution of 11 December2013, ${ }^{48}$ referring to the right of the parties to demand adjournment of a trial under S. $214 \$ 1$ of the CPC which, in certain circumstances, may be abused by the parties. In this context the Supreme Court claimed that the absence of the party caused by long-term sickness does not justify adjournment of a trial if in the facts of the case the motion for adjournment of a trial constitutes the abuse of procedural rights. In this context the Supreme Court attempted to contemplate the nature of the abuse of procedural rights in a wider way. In the opinion of the Supreme Court the autonomic construction of the abuse of rights under procedural law pursuant to S. 3 of CPC is still valid. Although the prohibition of abusing procedural rights has not so far been given the normative status, this construction is contemporarily in the legal science commonly accepted as the applicable principle of the procedural law and it is derived from the principle of fair process, the obligation of fair actions (consistent with good practice) of the participants in the proceedings and the purpose (essence) of the proceedings which in fact involves the real protection of individual rights resulting from the substantive law. This principle may be applied in the situation in which certain right is included in the procedural norm but using it serves a difference purpose than obtaining the protection of individual rights and the effect of exercising this right would contradict the procedural purpose of the provision and economy of the procedure. The prohibition of abusing procedural rights enables prevention of using the right contrary to the function of the provisions and may be significant for interpretation and application of procedural provisions by the court. The principle prohibiting the abuse of the procedural rights, formulated before the amendment to s. 3 CPC finds solid basis in it, as the clause of good practice included in the provision leads to imposing on the parties of the obligation of fair use of the rights they enjoy and refraining from abusing them. It has a significant impact also due to the reason that the Act does not provide for any general sanction applied in case of abuse of procedural rights and there are only individual special regulations which may be regarded as introducing a type of sanction (e.g. s. $103 \$ 1,213 \S 2,531$ first sentence of CPC). As a consequence, the prohibition of abusing procedural rights should be regarded, next to the principle of effectiveness and equality of rights of the parties, as a crucial element of the fair process. The court may and should counteract procedural steps taken by the party hampering the course of the proceedings and at the same time depriving the opponent of the possibility of obtaining effective protection. Correct application of this rule requires its consistency with procedural guarantees and respect for the right of recourse to court. Because of this the court may recognize that the exercise by a party of the procedural right constitutes an abuse of procedural rights only after scrupulous evaluation of the facts of the case, fully justifying the assertion that the action of the party is guided by unfair intention - different from the one provided for and accepted by the act - in particular the intention to hamper or prolong the proceedings. Taking into account the objective yardstick, the comparison of the purpose of the procedural right with the adequacy of using it in a specific way will be a useful criterion for the assessment. Summing up, the Supreme Court, expressing the essence of the abuse, assumed that the action contradicting good practice may consist in the fact that the steps provided for by the law and formally admissible are used contrary to the function of the provision, in a way not meeting the real purpose of the granted right and infringing the 
right of the other party to be granted effective legal protection. It can be claimed that also in this case the Supreme Court indirectly referred to the necessity of existence of the interest in taking a procedural step, assuming that lack of this interest is perceived as abuse if the steps provided for by the law and formally admissible are used contrary to the function of the provision and in a way not meeting the real purpose of the granted right. ${ }^{49}$

In the context of abuse of procedural rights contemplations included also the situations of submitting by the parties of multiple motions for disqualifying the judge. In particular, in the order dated 16 June $2016^{50}$ the Supreme Court asserted that multiple submission by the party of the motions for disqualification of the judge, based on the same general accusations, not possible to be verified and clearly destroying the dignity of the court, is classed as abuse of procedural rights. The court confirmed its previous stance that the prohibition of abusing procedural rights derived from the principle of fair and honest trial, the obligation of fair action of the participants in the proceedings compliant with good practice and the purpose (essence) of the civil proceedings enables prevention of using certain procedural right in a way which contradicts the function of the provisions and may be significant for the interpretation and application of the procedural provisions by the court and may translate into specific procedural decisions. In turn taking by the party the steps provided for in the Act and formally permissible, which however in the facts of a specific case are used contrary to the function of the provision, in the way not meeting the real purpose of the granted right and breaching the right of the other party to be granted effective legal protection contradicts good practice. ${ }^{51}$

Recently in the judgment of 27 July2018, V CSK 384/17 the Supreme Court found that the submission of a motion for calling for an attempt to conclude a settlement in certain situations may lead to the abuse of procedural right. The situation when the creditor submits a motion for calling for the attempt to conclude a settlement not with the purpose of meeting the claim by way of settlement but only to cause an interruption in the limitation period, is not analogous with the situation in which the creditor sues the debtor for payment of the receivable in circumstances in which using this receivable constitutes the abuse of individual right (S. 5 CC). Submission of the motion for calling for an attempt to conclude a settlement only to cause an interruption in the limitation period and not with the purpose of meeting the claim by way of settlement constitutes a case of improper use of the procedural right, where the effect, though desirable, is used in an unfair way and is of substantive nature. Taking a court action for payment in the circumstances where the use of the receivable constitutes the abuse of individual right serves the purpose of enforcing the claim. The usage of individual right (demand for payment) is subject to disqualification then, and whether simultaneously the procedural right to take court action is improperly used, is not important. Improper use of the procedural right to submit a motion for calling for an attempt to conclude the settlement, involving the submission of this motion to court only to obtain interruption in the limitation period and not - at least as well - in order to meet the claim by way of settlement should be regarded as the procedural step contradicting good practice

49 See also the judgment of SC of 25 March 2015, II CSK 443/14, (LEX no. 1730599).

50 Case file no.: V CSK 649/15 (SC Journal 2016 no. 9, Legalis) <www.sn.pl> accessed 10 June 2019. See also T Zembrzuski, 'Przeciwdziałanie nadużyciom w korzystaniu z instytucji wyłączenia sędziego w postępowaniu cywilnym' (2006) 2 Przegląd Sądowy 43.

51 See also the judgment of the Supreme Court - Civil Chamber of 25 November 2015 II CSK 752/14, Legalis, <www.sn.pl> accessed 10 June 2016. 
(S. 3 CPC) and, in particular, a subcategory of such a step,i.e. procedural step which leads to the abuse of the right to take such a step. ${ }^{52}$ A creditor who submits a motion for calling for an attempt to conclude the settlement, not to enforce his claim by way of settlement, but only to prolong the period of its appealability through causing an interruption in the limitation period contradicts good practice in the procedural meaning and acts against and abuses the procedural right. The conflict of the motion for calling for an attempt to conclude the settlement with good practice (S. 3 CPC) which takes place if the creditor abuses the right to submit it to the court, disqualifies this step and must result in inadmissibility of reconciliation procedure on this basis. Otherwise the court would not only authorize the abuse of procedural right allowing for reconciliation proceedings, but also would permit the situation where the dishonest purpose of the abuse is reached in the form of an interruption in the limitation period. In this situation there is no on the part of the creditor - abusing the procedural right to submit a motion calling for an attempt to conclude the settlement - legal interest worth protecting, as the interest in using the procedural right only for a purpose different than its intended use provided for by the legislator does not deserve protection.

To sum up, the abuse of procedural right is treated by the case law and literature as a separate institution. The evaluation in this aspect is effected within the frames of the judicial power by the court. According to the Supreme Court a useful criterion involves a comparison - taking into account an objective yardstick - of the purpose of a given procedural right with the adequacy of its use in a specific way, combined with scrupulous evaluation of the facts of the case..$^{53}$

Currently the institution of the abuse of procedural right is derived from general principles of the CPC and the clause of good practice included in s. 3 of CPC. Finally it should be indicated that the changes of the Civil Procedure Code are planned. Pursuant to the bill of the amendment to the Civil Procedure Code dated 27 November 2017, a new s. $4^{1}$ is scheduled to be incorporated in the CPC, worded as follows:

'S. 4 . The right provided for in the procedural provisions held by the parties to and participants in the proceedings cannot be used contrary to the purpose for which it was established (abuse of procedural right)'. In case the bill of the amendment to the CPC in the wording of 27 November 2017 becomes effective, also the consequences of the abuse of procedural right will be formalized. A new provision worded as follows is included in the bill of the amending Act: 'S. 226 ${ }^{2}$. After the court discovers the abuse by the party of the procedural right, the court may in the decision ending the proceedings:

1) impose a fine on the abuser;

2) irrespective of the result of the case, increase the costs of the proceedings to be paid by the abuser or even impose on the abuser the obligation to reimburse all the costs, proportionately to the delay in settling the case caused by the abuse;

3) at the request of the opposing party:

a) oblige the abuser to pay the costs of the proceedings increased by a proper amount reflecting the amount of work done by the opposing party to participate in the

52 Compare the resolution of the Supreme Court of 11 December 2013, III CZP 78/13, OSNC 2014, no. 9, item 87, the order of the Supreme Court of 16 June 2016, V CSK 649/15, OSNC 2017, no. 3, item 37.

53 See. Ereciński (n 1) 14. 
proceedings resulting from the abuse, however not higher than twice the amount of the costs;

b) oblige the abuser to pay the interest due on the said amount in the rate increased proportionally to the delay in settling the case caused by the abuse, however not higher than twice the amount'.

In effect, some consequences of the abuse of procedural right may burden the party as a result of submitting the motion by the opposing party and some may result from the independent action of the court.

\section{ABUSE OF RIGHT IN THE EUROPEAN CIVIL PROCEDURE}

Searching for the construction of the abuse of right in European procedural law requires a reference to abuse of right in European law in general. It seems to have been determined that in European law the principle of prohibition of abuse is of general nature, which is a natural feature of general principles of European law. ${ }^{54}$ It constitutes a general obligation to act in good faith and conduct fair process together with their limiting function. ${ }^{55}$ As a consequence, it has general application and requires the national courts to requalify the measures constituting the abuse of right or its circumvention in accordance with the reality, even in lack of national provisions transposing this principle. ${ }^{56}$ It constitutes authentic and autonomous source of EU law having constitutional status and being equivalent to treaties. They have significant impact on functioning and operation of the European Union as they fill the gaps and ensure flexibility of the law. ${ }^{57}$ Introduction of this principle in practice means balancing the situation between the legislator and the judiciary to the benefit of the latter and expansion of the role of judicial power. Within the judicial power the courts are given a real tool as institutions acting for the purpose of real protection of rights resulting from the EU law. Determination of the abuse leads to failure to apply relevant norm of the EU law. ${ }^{58}$ Refusal to grant the law or the benefit resulting from the EU law does not require special legal basis and takes place

54 Asin:F de Paul Tetang, 'La jurisprudence dela Cour de justice et du Tribunal del'Union européenne' (2018) 1 Revue du droit de l'Union européenne 245-254; RN Ionescu, 'Arrêt “Cussens e.a." (2018) 246 Journal de droit européen 49; S Denys, 'Principes généraux du droit' (2018) 1 Mois Comm 11-12; M Hennigfeld, 'Rechtsmissbrauch im Bereich des Unionsrechts' [2018] Betrieb 544-545; A Masuch, 'Unmittelbare Anwendbarkeit des Grundsatzes des Rechtsmissbrauchsverbots' [2018] Mehrwertsteuerrecht 225226; H Nieskens, 'Grundsatz vom Verbot rechtsmissbräuchlicher Gestaltungen' [2018] EU-UmsatzSteuerberater 7; BG Van Zadelhoff, 'Beslissingen in belastingzaken' (2018) 5BNB 1055; J Buckler, 'Ein neuer allgemeiner Rechtsgrundsatz: Das unionsrechtliche Missbrauchsverbot - Anmerkung zum Urteil des EuGH v. 22.11.2017, Rs. C-251/16 (Cussens u.a. / Brosnan)' [2018] Europarecht 371-380.

55 As in Lenaerts (n 3) 1153-1154.

56 According to CJEU's case law the application of the principle of prohibition of abuse towards the rights and benefits provided for by the EU law should take place irrespective of the fact whether the rights and benefits are justified under the treaties (with respect to basic freedoms see, in particular, judgments dated: 3 December1974 r., van Binsbergen, p. 13; 9 March 1999, Centros, s. 24), in the regulation (judgments: dated 6 April 2006, C-456/04, Agip Petroli SpA v. Capitaneria di porto di Siracusa et al., EU:C:2006:241, p. 19, 20; and also dated 13 March 2014, SICES et al., p. 29, 30) or in the directive (on VAT see in particular: dated 3 March 2005, Fini H, point 32; dated 21 February 2006, Halifax, p. 68, 69; and also dated 13 March 2014, C-107/13, FIRIN OOD v. Direktor na direkcija 'Obżałwane i danycznoosiguritetna praktika' Weliko Tyrnowo pri Centrałno uprawlenie na Nacjonatnata agencija za prichodite, EU:C:2014:151, p. 40).

57 Gajda - Roszczynialska (n 34) 490 - 620

58 See also judgment dated 28 July 2016, Kratzer, p 41, 42 and the case law quoted there. 
only because of the determination that in case of a fraud or abuse of right in reality the objective prerequisites required for gaining a desirable benefit are not met. ${ }^{59}$

This principle means that all the abusing behaviour is prohibited so thelegal entities cannot invoke the EU law norms for purposes constituting the abuse or their circumvention. ${ }^{60}$ In other words, they cannot fraudulently or abusively invoke or instrumentally use the EU provisions of the law. ${ }^{61}$ It is the national court which decides whether the abuse took place in accordance with the evidenciary rules provided for in the national regulations as long as it doesn't hamper the effectiveness of EU law. The national court in the main proceedings verifies whether the essential criteria are met with respect to existence of the abuse within the frames of 'abuse test.'. ${ }^{62}$ The national court should in accordance with the test verify both the objective and the subjective element. ${ }^{63}$ If necessary, through awarding the judgment in the preliminary ruling procedure the CJEU may set guidelines helping the national court in the interpretation effected by it. ${ }^{64}$.

The European civil procedure law does not contain any definition of the concept of abuse of the European civil procedure right. What is more, there are no general and overall norms which would create a general obligation of a fair and just process, binding the parties and their attorneys and preventing clearly incorrect or fraudulent actions of one party aimed at paralysing or undermining the defence of the other party. ${ }^{65}$ Anticipating further solutions, on the one hand, it should be indicated that there is no decision of CJEU which could clearly introduce a general principle of abuse of European right in civil procedure, ${ }^{66}$ deriving it as an autonomous principle or transferring it from the

59 See also judgments: dated 14 December2000, Emsland Stärke, p 56; dated 21 February 2006, Halifax, p 93; dated 4 June 2009, C-158/08, Agenzia Dogane Ufficio delle Dogane di Trieste v. Pometon SpA, EU:C:2009:349, p 28; dated 22 November 2017, C-251/16, Edward Cussens et al. v. T.G. Brosman, EU:C:2017:881, p 27.

60 Gajda - Roszczynialska (n 34) 490 - 620.

61 See judgments: dated 7February 1979, Knoors, p 25; dated 3 October 1990, C-61/89, criminal case against Marc Gaston Bouchoucha, EU:C:1990:343, p 14; dated 7 July 1992, Singh, p 24; dated 12 May 1998, Kefalas et al, p 20; dated 9 March 1999, Centros, p 24; dated 23 March 2000, Diamantis, p 33; dated 21 November 2002, C-436/00, X i Y v. Riksskatteverket, EU:C:2002:704, p 41, 45; dated 30 September 2003, C-167/01, Kamer van Koophandel en Fabrieken voor Amsterdam v. Inspire Art Ltd, EU:C:2003:512, p 136; dated 21 February 2006, Halifax et al, p 68; dated 12 September 2006, Cadbury Schweppes and Cadbury Schweppes Overseas, p 35; dated 21 February 2008, Part Service, p 42; dated 25 July 2008, Metock et al, p. 75; dated 2 June 2010, C-118/09, Robert Koller, EU:C:2010:805, p 81.

62 See instead of many: 22 November 2017 Cussens et al, p 59.

63 More information in: Klöpfer (n 8) 176 et seq.

64 See instead of many: judgment dated 22 November 2017, Cussens et al, p 59; dated 21 February 2006, Halifax, p 76, 77; and also dated 17 December 2015, C-419/14, WebMindLicenses kft v. Nemzeti Adó- és Vámhivatal Kiemelt Adó- és Vám Főigazgatóság, EU:C:2015:832, p 34.

65 See F Mancini, 'Short note on abuse of procedure in community law' in M Taruffo (ed), Abuse of procedural rights: comparative standards of procedural fairness (Kluwer Law International 1999) 233. However, there are opinions trying to derive from contextuality or purposefulness the existence of the concept of abuse of rights from Art 7 and Art 8 of the Regulation 1215/2012 or Art 10 of the Regulation $650 / 2012$ (see more in Klöpfer (n 8) 315-352). It should be noted that there is a legal norm directly referring to the concept of bad faith in the context of process. Under S. 139 of the consolidated text of the regulation on procedure before the Court of Justice dated 25 September 2012: 'Unjustified costs or those resulting from bad faith The CJ may be imposed on the party even if the party won the case, the obligation to reimburse the cost incurred by the opposing party which in CJ's opinion resulted from the first party acting without justification or in bad faith'. See also judgment dated 1 June 1983, 36/81, 37/81 and 218/81, Peter Willem Seton v. Komisja, EU:C:1983:152; judgment dated 3 March 1993, T-44/92, Claudia Delloye et al. v. Commission, EU:T:1993:18.

Klöpfer (n 8) 53. 
general principles, ${ }^{67}$ not to mention the creation by litigators of own definition which would refer to the prohibition of abuse of the right in this context. ${ }^{68}$ On the other hand, due to the principle of certainty and mutual trust or due to the necessity of avoiding parallel proceedings ${ }^{69}$ and conflicting settlements and also the necessity of uniform application of European law the $\mathrm{CJ}$ many times spoke about the abuse of the European civil procedure right in a context. ${ }^{70}$

Discussion on the abuse of the European civil procedure right requires a new look at the principle of procedural and organizational autonomy. ${ }^{71}$ The procedural law and the court law connected therewith are unquestionably attributed to the public law, so, as a principle, its application is dominated by national legislation and national interpretation. This assumption formed the basis for procedural and organizational autonomy principle $^{72}$ based on Rewe/Comet doctrine. ${ }^{73}$ In lack of EU law, the implementation of the legal norms adopted by the European legal system is entrusted, as a principle, to the judiciary of the Member States with the application of procedures established in particular states as long as particular Member States are obliged to guarantee effective standards of protection existing in EU law. ${ }^{74}$ Originally the limits of assuming the competences were set by: equivalence principle and effectiveness principle and the primacy principle and direct application of EU law principle connected therewith. ${ }^{75}$ A special role is fulfilled in this aspect both by CJEU and the national courts which within the judicial power perform the function of the guarantor of full effectiveness of EU law, balancing the obligation of determination by Member States of procedural rules and organization of courts. ${ }^{76}$ Even today CJEU, overcoming the rule of procedural autonomy in civil procedure created already some minimal standards with respect

67 See, however, in the context of the insolvency law the judgment of Vinyls Italia SpA.

68 See Taruffo (n 17) 7; Mancini (n 66) 234.

69 Discussion on the issue of parallel proceedings see B Trocha, Zawisłośćsprawy przed sadem zagranicznym w postępowaniu cywilnym (Wolters Kluwer 2018) 17 at seq. and the literature quoted there.

$70 \quad$ Klöpfer (n 8) 313.

71 See Gajda - Roszczynialska (n 34) 490 - 620.

72 B Hess, 'The State of the Civil Justice Union' in B Hess, M Bergström, E Storsrubb (eds), EU Civil Justice. Current issues and future outlook (2016) 7 Swedish Studies in European Law, Oxford-Portland p. 1.

73 Formulated under the decision dated 16 December 1976, 33/76, Rewe-Zetralfinanz eG i Rewe-Zentral $A G$ v. Landwirtschaftskammer für das Saarland, EU:C:1976:188.

74 See instead of many others: K Lenaerts, 'National Remedies for Private Parties in The Light of The Eu Law Principles of Equivalence and Effectiveness' (2011) 46 Irish Jurist New Series 13-37; A Nylund, B Krans, 'The European Union and national civil procedure - a rocky road or a smooth proces?' in A Nylund, B Krans (eds), The European Union and National Civil Procedure (Intersentia 2016) 1 et seq; G Rodriguez Iglesias, 'Zu den Grenzen der verfahrensrechtlichen Autonomie der Mitgliedstaaten bei der Anwendung des Gemainschaftrecht' [1997] Europeische Grundrechtzeitung 298 et seq; CN Kakouris, 'Do the Member States Possess Judicial Procedural Autonomy?' 1997 (34) CML Rev 1389 et seq.; A Wróbel, 'Autonomia proceduralna państw członkowskich. Zasada efektywności i zasada efektywnej ochrony sądowej w prawie Unii Europejskiej' (2005) 1 Ruch Prawniczy, Ekonomiczny i Socjologiczny 39; M Domagalska, 'Zasada autonomii proceduralnej państw członkowskich i jej ograniczenia wynikające z zasady efektywności' in ed. M. Szwarc-Kuczer, K. Kowalik-Bańczyk (eds), Stosowanie prawa Unii Europejskiej przez sądy: Zasady - orzecznictwo piśmiennictwo, (vol II, Wolters Kluwer 2007) 326 et seq. TT Koncewicz, Sędziowie krajowi..., p. 123-160.

75 See M Dougan, National Remedies Before the Court of Justice(Hart Publishing 2004) 4 et seq.

76 See. K Lenaerts, 'The Role of Law and the Coherence of the Judicial System of the European Union' [2007] CML Rev 1659, 1645-1650. 
to national procedures. ${ }^{77}$ In this context the discussion on the prohibition of abuse of right in European civil procedure apparently seems to be mutually in conflict. On the one hand, there are numerous decisions which are interpreted in the literature as rejection of the concept of applying the institution of abuse of rights in European court proceedings, on the other hand, there are numerous examples where the case law in fact selectively applies the concept of prohibition of abuse of right in European civil procedure ${ }^{78}$ even though it is not clearly stated. ${ }^{79}$ Based on this case law it is determined that the correction of certain norms of procedural law is advisable on the basis of the principles such as good faith, morality, honesty, justice in European civil proceedings and national procedures. ${ }^{80}$ Even if we assume that the interpretation is too far-reaching then CJEU undoubtedly is not indifferent in this case, which results directly from the speech of the General Spokesman Tesauro ${ }^{81}$ concerning Tatry case ${ }^{82}$ or the speech of the General Spokesman Mengozzi concerning the case Freeport plc v. Olle Arnoldsson. ${ }^{83} \mathrm{We}$

77 B Hess, 'The State of the Civil Justice Union' in B Hess, M Bergström, \& E Storskrubb (eds), EU Civil Justice: Current Issues and Future Outlook (Hart Publishing 2016) 15-16.

78 A Nuyts, 'The Enforcement of Jurisdiction Agreements Further to Gasser and the Community Principle of Abuse of Rights' in] Forum Shopping in the European Judicial Area (Hart Publishing 2007) 55, 67.

79 G Cuniberti, 'The Discreet Influence of Abuse of Law in International Civil Procedure' in R de La Feria, S Vogenauer (eds), Prohibition of Abuse of Law: A New General Principle of EU Law?(Studies of the Oxford Institute of European and Comparative Law, vol 13, Hart Publishing 2011) 279, 283.

$80 \quad$ Klöpfer (n 8) 178 et seq.

81 In his opinion the spokesman clearly indicated: 'In that regard, it should be noted, however, that such efforts constituting forum shopping are easiest to deploy in systems in which priority is automatically given to the connecting factor of the lex fori, however disguised. Where, conversely, the rules of private international law or the case-law, or both, adopt connecting factors which better correspond to the nature and characteristics of the relationship, and to the expectations of the parties who originally created it and 'devised it', the possibilities of biased or even abusive use of procedural and private international law, as a whole, are also reduced. In any event, it will be incumbent upon the court seised to ensure that any abuse is thwarted'.

82 Judgment dated 6 December 1994 C-406/92, The owners of the cargo lately laden on board the ship 'Tatry' $v$. the owners of the ship 'Maciej Rataj', EU:C:1994:400. Compare H Tagaras, 'Chronique de jurisprudence de la Cour de justice relative à la Convention de Bruxelles. Années judiciaires 1994-1995 et 1995-1996’ [1997] Cahiers de droit européen 164-171; Ch Wolf, 'Rechtshängigkeit und Verfahrenskonnexität nach EuGVÜ' [1995] Europäische Zeitschrift für Wirtschaftsrecht” 365-367; RA. Borrás, 'Jurisprudencia del Tribunal de Justicia de las Comunidades Europeas' [1995] Revista Jurídica de Catalunya 827-831; E Ullmann, 'Die Verwarnung aus Schutzrechten - mehr als eine Meinungsäußerung?' [2001] Gewerblicher Rechtsschutz und Urheberrecht 1027-1032; L Klesta Dosi, 'Corte di giustizia delle Comunità europee ( $1^{\circ}$ ottobre 1994 30 aprile 1995)' (1995) II La nuova giurisprudenza civile commentata 391-393; E Tichadou, Revue critique de droit international privé (1995) 601-609; M Lenenbach, 'Gerichtsstand des Sachzusammenhangs nach Art. 21 EuGVÜ?' [1995] Europäisches Wirtschafts- \& Steuerrecht 361-367; P Huber, 'Fragen zur Rechtshängigkeit im Rahmen des EuGVÜ - Deutliche Worte des EuGH’ [1995] Juristenzeitung 603-611; H Schack, 'Gerechtigkeit durch weniger Verfahren' [1996] Praxis des internationalen Privatund Verfahrensrechts 80-83; A Huet, 'Chronique de jurisprudence du Tribunal et de la Cour de justice des Communautés européennes' [1995] Journal du droit international 469-476; R Fentiman, 'Tactical Declarations and the Brussels Convention' [1995] The Cambridge Law Journal 261-263; R Arroyo Montero, 'Interpretación del Convenio de Bruselas a partir de sus objetivos: Avances en materia de litispendencia y conexidad' (1995) 94 La ley - Comunidades Europeas 1-5; JJ Alvarez Rubio, 'La regla de especialidad en el art. 57 del Convenio de Bruselas de 1968 sobre embargo preventivo de buques' [1995] Anuario del Derecho Marítimo 273-312; P Mankowski, 'Spezialabkommen und EuGVÜ' [1996] Europäisches Wirtschafts- \& Steuerrecht 301-305; A Pesce, 'Materie speciali, litispendenza e connessione di causa nella interpretazione della Corte di giustizia delle CE' (1995) 1 Giurisprudenza italiana 929-936; BJ Davenport, 'Forum Shopping in the Market' [1995] The Law Quarterly Review 366-371; TC Hartley, 'Admiralty Actions under the Brussels Convention' [1995] European Law Review 409-414; A Briggs, 'The Brussels Convention tames the Arrest Convention' [1995] Lloyd's Maritime and Commercial Law Quarterly 161-166; P Volken, 'Rechtsprechung zum Lugano-Übereinkommen (1993/94)' [1995] Schweizerische Zeitschrift für internationales und europäisches Recht 332-334.

83 Points 48-63 of the opinion related to the judgment of CJ (third chamber) dated 11 November 2007, C-98/06, Freeport plc v. Olle Arnoldsson, EU:C:2007:595. 
should also mention the last judgment in the case of Vinyls Italia SpA v. Mediterranea di Navigazione SpA. ${ }^{84}$ Specific statements of CJEU in the context of the prohibition of abuse of procedural right in broadly defined European civil procedure refer to various matters, in particular with respect to the abuse of the right to start an action or the right of defence in European civil procedural law (e.g. filing a ficticious action, if and when the action for compensation may be deemed a procedural abuse, incorrect use of pleadings), or obtaining jurisdiction under false pretenses typical of the European procedural law, in particular malus forum shopping and the so-called torpedo actions. ${ }^{85}$

\subsection{ABUSE OF THE RIGHT TO FILE AN ACTION AND THE RIGHT OF DEFENCE IN EUROPEAN PROCEDURAL RIGHT}

In European civil procedural law in the objective aspect we may distinguish abuse of right to file an action from abuse of particular procedural measures within the procedural steps taken during the process. ${ }^{86}$

The literature indicates that some situations of filing an action may be treated as abuse of procedural right. ${ }^{87}$ In particular, authors give fictitious action as an example ${ }^{88}$. It is also indicated that the actions for compensation may be treated as inadmissible due to abuse of procedural right if inappropriately used in place of action for annulment, in particular, if the action was filed to avoid the consequences of the lapse of time provided for lodging the appeal concerning annulment. ${ }^{89}$ In the judgment dated 23 November 2004, T-166/98, Cantina sociale di Dolianova Soc. coop rl et al. v. Commission of the European Communities, ${ }^{90}$ the $\mathrm{CJ}$ found that the filed complaint about the compensation in fact aimed at repealing the individual decision addressed to the entities lodging the complaint, which was final and binding, as a result of which it would have the same subject matter and the same effect as the complaint about annulment - as a consequence it could be deemed a procedural abuse. ${ }^{91}$ The abuse of the right to initiate action in the

84 Compare C Nourissat, 'Révocation d'un paiement intervenu avant l'ouverture de la faillite' (2017) 8-9 Procédures 19; L Idot, 'Actes préjudiciables à la masse Europe' (2017) 337 Août Comm 45-46; D Berlin, 'Limites à l'autonomie procédurale' (2017) 25 La Semaine Juridique - édition générale 1215; L D’Avout, 'Le contrat artificiellement internationalisé devant la Cour de justice (un naufrage juridique)' (2017) 38 La Semaine Juridique - édition générale 1655; Ch Dumont, 'Arrêt de la CJUE du 8 juin 2017 (affaire C-54/16) - Vinyls Italia SpA, en faillite, c/ Mediterranea di Navigazione SpA' [2017] JurisNews 81-83.

85 Gajda - Roszczynialska (n 34) 490 - 620.

86 Gajda - Roszczynialska (n 34) 490 - 620.

87 Gajda - Roszczynialska (n 34) 490 - 620.

88 See Mancini (n 66) 234. See also K Lenaerts, I Maselis, K Gutman, EU Procedural Law (OUP 2014) 93-94 and the case law quoted there.

89 See Lenaerts, Maselis, Gutman (n 89) 490-492 and the case law quoted there.

90 EU:T:2004:337. As in judgment dated 24 May 2011, T-489/08, Power-One Italy SpA v. European Commission, EU:T:2011:238.

91 Comments on the decision see: AL Mosbrucker, 'Recevabilié du recours en indemnité (2008) 10 (297) Europe 13-14; J Prostor, 'Zahtevek podizvajalca do naročnika posla' (2011) 5 Podjetje in delo 823-835. Similarly: the order of 1st Instance Court dated 4 May2005, T-86/03, Holcim (France) SA, former Groupe Origny SA, based in Paris (France), v. Commision of European Communities, EU:T:2006:90. E Barbier de La Serre, 'Autonomie des voies de droit et paiement d'intérêts après l'annulation d'une amende' (2005) 4 Revue Lamy de la Concurrence: droit, économie, régulation 70-71. Compare also the last judgment of CJEU dated 28 February 2018, T 292/15, Vakakis kai Synergates - Symvouloi gia Agrotiki Anaptixi AE Meleton, dawniej Vakakis International - Symvouloi gia Agrotiki Anaptixi AE, based in Athens (Greec), v. European Commission, EU:T:2018:103. See also F Gazin, 'Responsabilité extracontractuelle' (2018) 04 (4) Europe 21-22. 
European civil procedural law takes place e.g. in a situation where the petitioner starts the action being aware that he lacks legal interest. With respect to abuse of right to initiate action other situations include the initiation of the action with the breach of res iudicata principle, while the other - to settle the case despite the lapse of limitation period. ${ }^{92}$ The action filed only with the purpose of bullying, threatening or insulting the opposing party is also considered to be abuse. In this case usually repetitive litigation $n^{93}$ is mentioned as an example. The petitioner filing subsequent actions against the same defendant in the same case assumes that at least one of them is likely to end in a favourable decision for him. Within the defence undertaken, the abuse of right may consist also in instigation of the action by the entity which in the parallel action instigated earlier functions as the defendent (so-called reactive litigation). ${ }^{94}$ In particular, it can happen in the situation where the petitioner knows that the claim lodged against him is well-founded and despite this files an action aiming at determination of lack of grounds for holding him liable, relying on the fact that multiplicity of actions may contribute to making a mistake by the opponent and reducing his chances to lose in the first action. This can be illustrated with the example when instigation of a parallel action is only of demonstrative nature and aims at putting psychological pressure meaning that the opponent will not give up without fight, which in certain situations may be a motivation for concluding a settlement. ${ }^{95}$

The doctrine assumes that there are situations in which the parties may inappropriately use documents to which they gained access during the court proceedings and such behaviour may be deemed abuse of procedural right. ${ }^{96}$ Hence CJEU's case law confirms that offering access to pleadings by the party to third parties in a situation where such documents were not delivered for the purpose of defending the interests of this party may constitute procedural abuse. ${ }^{97}$ So if the party uses such documents for the purpose

92 Taruffo (n 17) 16.

93 See Trocha (n 70) 43.

94 See Trocha (n 70) 43; L Palsson, 'The Institute of lis pendens in international Civil Procedure'(1970) 14 Scandinavian Studies In Law 83. Compare however K Weitz, Jurysdykcja krajowa w postepowaniu cywilnym (Wydawnictwo Prawo i Praktyka Gospodarcza 2005) 316.

95 See Gajda - Roszczynialska (n 34) 490- 620 and the literature quoted there.

96 See Lenaerts, Maselis, Gutman (n 89) 821-822 and the case law quoted there.

97 As in: judgment dated 14 November 2012, Nexans France SAS, point 108. Comments on the decision see: F Puel, 'Nexans: Some Limitations to Inspections Carried Out by the European Commission in the Context of Investigations' (2013) 4 Journal of European Competition Law \& Practice 312-314; J Probst, F Lutz, 'La jurisprudence de la Cour de justice et du Tribunal de l'Union européenne. Chronique des arrêts. Arrêt "Nexans"' (2013) 1 Revue du droit de l'Union européenne192-198; L Idot, 'Déroulement des inspections sur décision' (2013) 1 Europe 39-40; A Laghezza, 'From the Nexans judgment to the "next" improvements of the EU dawn raid procedure?' [2013] European Competition Law Review 214-217; F Picod, 'Annulation partielle d'une décision d'inspection' (2012) 48 La Semaine Juridique édition générale 2154. Analogously the judgment dated 17 June 1998, Svenska Journalistförbundet, point 139. Comments on the decision see: P Pallaro, 'Nuove conquiste per il diritto di accesso ai documenti delle istituzioni comunitarie' [1999] Diritto cromunitario e degli scambi internazionali 695719; M Novak-Stief, 'Zugang der Öffentlichkeit zu Ratsdokumenten' [1998] European Law Reporter 440-441; I Österdahl, 'Case T-124/96, Interporc Im- und Export GmbH v. Commission, Judgment of 6 February 1998, [1998] ECR II-0231; Case T-83/96, Gerard van der Wal v. Commission, Judgment of 19 March 1998, [1998] ECR II-0545; Case T-174/95, Svenska Journalistförbundet v. Council of the European Union, Judgment of 17 June 1998, [1998] ECR II-2289’ (1999) 36 (5) Common Market Law Review 1059-1077; M Kuijer, 'De zaak Svenska; inzage in documenten van de Raad en misbruik van recht door publicatie van processtukken op Internet' [1998] Nederlands tijdschrift voor Europees recht 270-274; Y Gautier, 'Chronique de jurisprudence du Tribunal et de la Cour de justice des Communautés européennes' [1999] Journal du droit international 514-518; G Romano, (1999) 4 Il Foro italiano 2022; F Berrod, D Ritleng, (1998/8-9) 271 Europe 11-12. 
other than conducting his own action, e.g. to provoke certain social reactions, triggering public criticism through obtaining the documents within disclosure or exerting influence on the party through public opinion and with this intention he delivers the documents to third parties, then it may be treated as abuse of right. Such an abuse of process may be sanctioned e.g. by decision on costs. ${ }^{98}$

\subsection{ABUSE OF RIGHT UNDER REGULATION OF COUNCIL (EC) $1346 / 2000$ DATED 29 MAY 2000 ON INSOLVENCY PROCEEDINGS AND REGULATION NO. 2015/848 DATED 20 MAY $2015^{99}$}

In the judgment concerning Vinyls Italia $\mathrm{SpA}^{100} \mathrm{CJ}$ found that Art. 13 of regulation no. 1346/2000 can be efficiently invoked in a situation where the parties to the contract who are based in the same Member Country in whose territory all the other essential elements of a given situation are located, indicated the governing law concerning the contract of another Member Country on condition that they did not choose the governing law in a fraudulent or abusive way, which is to be established by the referring court. On the basis of the same insolvency law CJ clearly referred to the concept of abuse of right and transferred the general rule prohibiting the abuse of right to the jurisdictional norm. In particular the CJ reminded in this context that according to its established case law defendants cannot invoke EU law norms in a way constituting a fraud or abuse. ${ }^{101}$ It also referred to a general abuse test indicating that in this context the established case law suggests that determination of existence of the practice constituting an abuse requires meeting the objective and subjective factors. Firstly, as for the objective factor, for the determination it is necessary that the overall objective circumstances would indicate that despite formal observance of conditions provided for in EU regulations the purpose intended to be met by the regulations was not met. Secondly, such a determination requires also a subjective factor, namely that the overall objective circumstances would indicate that the main purpose of the step is to gain unlawful benefit. Prohibition of the practice constituting the abuse is groundless if certain transactions may be justified in another way than only benefit gaining. ${ }^{102} \mathrm{CJ}$ held also that for the purpose of establishing the existence of the second factor connected with the intention of the parties we may inter alia take into account purely artificial nature of the transactions. It is the referring court which has to examine, according to evidential rules provided for in the national regulations, on condition it does not lead to hampering the efficacy of EU law, whether in the proceedings pending before such a court the prerequisites for practice constituting an abuse have been met. ${ }^{103}$ The content of the decision indicates clearly that CJ applied the abuse test on the procedural basis within the insolvency law in the context of

98 As in Lenaerts, Maselis, Gutman (n 89) 821.

99 Official Journal EU L 160, p 1.

100 Judgement dated 8 June 2017, Vinyls Italia SpA. Compare: Nourissat (n 85) 19; Idot (n 85) 45-46; Berlin(n 85) 1215; D’Avout (n 85) 1655; Dumont (n 85) 81-83.

101 As in judgment dated 8 June 2017, Vinyls Italia SpA, point 51.

102 As in judgment dated 28 July 2016, Kratzer, point 38-40 and the case law quoted there; the judgment dated 8 June 2017, Vinyls Italia SpA, point 52.

103 As in judgment dated 28 July 2016, Kratzer, point 41, 42 and the case law quoted there; judgment dated 8 June 2017, Vinyls Italia SpA, point 53. 
Art. 13 of regulation No. 1346/2000. To sum up, the decision means transferring the general principle prohibiting the abuse of right into the insolvency law area. ${ }^{104}$

\subsection{ABUSE OF PROCEDURAL RIGHTS UNDER REGULATION OF COUNCIL (EC) 44/2001 DATED 22 DECEMBER 2000 ON JURISDICTION AND THE RECOGNITION OF COURT DECISIONS AND ENFORCEMENT IN CIVIL AND COMMERCIAL CASES AND REGULATION OF EUROPEAN PARLIAMENT AND COUNCIL (EU) NO. 1215/2012 DATED 12 DECEMBER 2012 ON JURISDICTION AND RECOGNITION OF COURT DECISIONS AND ENFORCEMENT IN CIVIL AND COMMERCIAL CASES}

Abuse of European procedural right in the scope of jurisdiction is mostly connected with the so-called trading in jurisdiction or more precisely 'obtaining jurisdiction under false pretenses' and torpedo actions. ${ }^{105}$ The national jurisdiction is based on an assumption of granting the courts of a given state international jurisdiction to hear and settle a given case through jurisdictional norms. ${ }^{106}$ Disregarding here wide discussion about the legal nature of the jurisdictional norm (substantive or relating to conflicts of law $)^{107}$ it should be stated that undeniably the priority element of these norms consists in jurisdictional connecting factors, namely those facts (relating to the person or the subject matter) which link the case to the territory of a given state. ${ }^{108}$ Introduction of certain jurisdictional connecting factors per se will not always lead to autonomic and exclusive definition of competence areas of particular states. In a sense competitiveness of jurisdiction is always a natural condition. ${ }^{109}$ There can be positive or negative jurisdictional conflicts. What is especially significant from the analysed point of view is the positive jurisdictional conflicts. A potential positive jurisdictional conflict in the form of multitude jurisdictional grounds which can be taken into account is connected with forum shopping. Forum shopping in a simplified version means petitioner's strategy consisting in trying to move the case from its 'natural forum (where he is established)' to be settled in 'the foreign forum' which is to guarantee a bigger chance of obtaining favourable decision or other benefits. ${ }^{110}$ This manipulation, with preservation of certain

104 As in: Gajda - Roszczynialska (n 34) 490 - 620.

105 Gajda - Roszczynialska (n 34) 490 - 620.

106 See Weitz (n 95) 39 et seq; T Ereciński, Międzynarodowe postępowanie cywilne (ed T Ereciński, J Ciszewski, PWN 2000) 70; A Torbus, Umowa jurysdykcyjna w systemie międzynarodowego postępowania cywilnego (TNOiK 2012) 39 et seq.

107 More information in: Torbus(n 107) 77-88.

108 Ereciński (n 107) 70.

109 See Ereciński (n 107) 56. See also MA Lupoi, 'The New Lis Pendens Provision in the Brussels I and II Regulations' (2002) 7 ZZP 153.

110 See judgment dated 13 July 2006, C-539/03, Roche Nederland BV et al. v. Frederick Primus and Milton Goldenberg, EU:C:2006:458, point 38. Compare also R Conti, R Foglia, 'Contraffazione di brevetti e pluralità di convenuti' [2006] Il Corriere giuridico 1453-1455; S Warner, S Middlemiss, 'Patent Litigation in Multiple Jurisdictions: An End to Cross-border Relief in Europe?' [2006] European Intellectual Property Review 580-585; S Alvarez González, M Requejo Isidro, 'Litigación internacional sobre patentes en Europa. El sistema de competencia judicial internacional interpretado por el TJCE (Reflexiones tras las sentencias del TJCE de 13 de julio de 2006 en los casos GAT y ROCHE)' [2006] Actas de derecho industrial y derecho de autor 661-677; M Wilderspin, 'La compétence juridictionnelle en matière de litiges concernant la violation des droits de propriété intellectuelle. Les arrêts de la Cour de justice dans les affaires C-4/03, GAT c. LUK et C-539/03, Roche Nederland c. Primus et Goldberg' [2006] Revue critique de droit international privé 777-809; R Knaak, 'Internationale Zuständigkeiten und Möglichkeiten des 
conditions, is usually perceived negatively, in particular if it is connected with artificial creation of conditions contrary to the purpose of the regulation. ${ }^{111}$ On the other hand, forum shopping per se does not have to be an abuse automatically. It is indicated that elimination of insecurity with respect to jurisdiction of the court of a given state is connected with the fact whether the selection of national jurisdiction allowing for the hearing of the case by court which from the parties' point of view is beneficial, is not undesired. ${ }^{112}$

In practice the abuse of forum shopping will have a limited scope, though. In principle, the freedom of choice of jurisdiction by the petitioner with respect to alternatively various courts having jurisdiction should not be limited only because the choice of jurisdiction is bound to have certain negative results. Such negative results should be qualified. Abuse in this context not always has to be treated as an exception. ${ }^{113}$ Actions of the abuser should directly consist in acting against the legal norm or its circumvention, but also may be deemed inadmissible only if it leads to unlawful trading in grounds for national jurisdiction or in another way breaches good procedural practice. In the objective aspect we may deal with an abuse if trading in jurisdiction aims at dishonest or fraudulent obtaining of jurisdiction under false pretenses as a benefit of one of the parties, which contradicts the effect provided for by the legal norm or act ${ }^{114}$. In the subjective aspect an abuse of right takes place if as a result of trading in jurisdiction the party obtains unlawful personal benefit (taking into account the objective aspect, i.e. to the detriment of the other party and against the intended purpose of the norm $)^{115}$. It means that in practice the abuse of forum shopping takes place each time in a given case when the freedom of choice of jurisdiction is not the real reason for taking advantage by the petitioner of the freedom of choice in the internal market and the choice of jurisdiction aims solely at harming the defendant and creating high costs to be paid by him in a way constituting a gross abuse or fraud. ${ }^{116}$

forum shopping in Gemeinschaftsmarkensachen - Auswirkungen der EuGH-Urteile Roche Niederlande und GAT/LUK auf das Gemeinschaftsmarkenrecht' [2007] Gewerblicher Rechtsschutz und Urheberrecht, internationaler Teil 386-394; A Wittwer, 'Patentrecht im Doppelpack - zwei weitreichende Entscheidungen zur internationalen Zuständigkeit bei Patentverletzungen' [2006] European Law Reporter 391-394; P Lange, 'Der internationale Gerichtsstand der Streitgenossenschaft im Kennzeichenrecht im Lichte der "Roche/Primus" - Entscheidung des EuGH' [2007] Gewerblicher Rechtsschutz und Urheberrecht 107-114; J Adolphsen, 'Renationalisierung von Patentstreitigkeiten in Europa' [2007] Praxis des internationalen Privat- und Verfahrensrechts 15-21; A Kur, A Metzger, 'Exclusive jurisdiction and cross border IP (patent) infringement suggestions for amendment of the Brussels I regulation' [2007] Intellectuele eigendom \& Reclamerecht 1-8; C Galli, 'La Corte di giustizia restringe drasticamente lo spazio per le azioni cross-border in materia di brevetti' [2006] Il Corriere giuridico 146-150.

111 See Klöpfer (n 8) 370-371; P Vareilles-Somieres, Forum Shopping in The European Judicial Area (Hart Publishing 2007); A Bell, Forum Shopping and Venue in Transnational Litigation (OUP 2003); F Jünger, 'Forum Shopping. Domestic and International'(1989) 63 Tulane Law Review 553-572; ChA Whylock, 'The evolving Forum Shoping System' (2011) 96 Cornell Law Review 481-534; F Ferrari, 'Forum Shoping, A Plea for a Broad and Value Neutral Definition' in W Wurmnest, P Mankowski (eds) Festschrift fur Ulrich Magnus: zum 70. Geburtstag, (Sellier 2014) 385-401; LE Salles, Forum Shopping in International Adjudication. The Role of Preliminary Objections (CUP 2014); D Jasper, Forum shopping in England und Deutschland (Duncker \& Humblot 1990).

112 As in K Siehr," "Forum Shopping” im internationalen Rechtsverkehr' (1984) 25 ZfRV 124.

113 See Klöpfer (n 8) 371.

114 See Ch Thole, 'Missbrauchskontrolle im europäischen Zivilverfahrensrecht - zur Problematik der sog. Zuständigkeitserschleichung' (20090 122 ZZP 423, 428; D Coester-Waltjen, 'Von der Fledermaus zum Torpedo? - Rechtsmissbrauch im internationalen Verfahrensrecht' (2011) LII Annales Universitatis Scientiarum Budapestinensis De Rolando Eötvös Nominatae Sectio Iuridica 226.

115 See Klöpfer (n 8) 372.

116 Gajda - Roszczynialska (n 34) 490 - 620. 
One of the classic examples includes torpedo actions. ${ }^{117}$ They originate from the situation where one party blocks, claiming lis pendens, a court action aimed at awarding benefit through earlier filing an action for determination of non-existence of the right ${ }^{118}$ ${ }^{119}$ and from the way the lis pendens is regulated in European civil procedural law and interpretation of this institution. This issue was a subject of interest on the basis of the regulation No. 44/2001 and despite the changes it is still debated under regulation No. $1215 / 2012$. The issue of torpedo actions appeared already in Brussels Convention and then regulation No. 44/2001 and was boiled down to applying a particular defence tactics consisting in blocking the action for awarding the benefit through earlier instigation of the action for determination. The action for determination was filed in such a state where it was the most favourable for the petitioner expecting to be sued (a potential defendant). On multiple occasions the aims of such actions analysed from the perspective of fair process in good faith were debatable, in particular if the aim was to postpone the award of the judgment awarding the benefit due to the expected length of the proceedings. It is because the blockade activated as mentioned above having usually the form of suspension of the proceedings may entail additional obstacles if the administration of justice in the state where the action was instigated earlier has the reputation of protracting proceedings. ${ }^{120}$ Initiation of such an action in countries such as Italy or Belgium often led to the necessity of lengthy examination of jurisdiction. Pending the action determining jurisdiction, and if this issue is settled in a positive way, then till the end of the action as for the substance, the right held by the petitioner is in fact paralysed (about a year or more). ${ }^{121}$ This situation took place mainly in actions instigated in Italy as well as Belgium. That is why this practice is called the Italian or the Belgian torpedo and is a very topical issue in the literature. ${ }^{122}$

In the European area we may observe dual activity. On the one hand, CJEU's case law on a case-to-case basis indicates which situations create obstacles in applying a given jurisdictional connecting factor provided for in the provision, both in case of multiple meanings of notions, as well as in case of multitude of grounds - if the aim is different than the one for which the right was granted (both if the application turns out to be fraudulent and when it leads to abuse of the right to which the petitioner is entitled). On the other hand, creation by the legislator of other specific legislation mechanisms aimed at protection against abuse of the right concerning jurisdiction, especially against the so-called malus forum shopping and torpedo actions is very typical. ${ }^{123}$

The subject of prohibition of abusing the right in the scope of jurisdiction in civil proceedings in civil and commercial matters has been discussed by the CJ since the $90 \mathrm{~s}$

117 Compare Klöpfer (n 8) 303 et seq.

118 Compare K Weitz, 'Procesowe znaczenie zawisłości sprawy przed sądem zagranicznym (uwagi de lege ferenda na tle prawnoporównaczym)' (2003) 1 Kwartalnik Prawa Prywatnego.

119 Compare P Grzegorczyk, 'Zawisłość sprawy przed sądem zagranicznym w sprawach o naruszenie praw własności przemysłowej' (2006) 6 Europejski Przegląd Sądowy 23-24.

120 Trocha (n 70) 44.

121 Comments on this issue see $\mathrm{K}$ Schmehl, Parallelverfahren und Justizgewährung: zur Verfahrenskoordination (Tübingen 2011).

122 Compare Klöpfer (n 8) 303 et seq; P. Grzegorczyk, Zawisłość sprawy..., p. 24 et seq. and the literature quoted there and Gajda - Roszczynialska (n 34) 490 - 620.

123 Gajda - Roszczynialska (n 34) 490 - 620. 
of the previous century. We can assume that in concreto the possibility of applying the jurisdictional norms defined in the decision is fortified with the limitation in the form of 'abuse of the grounds for court jurisdiction' which takes place if the application of such norms results from petitioner's manipulation with respect to vagueness of notions, multitude of grounds, contractual provisions, resulting in excluding the relation forming the subject matter of the proceedings from the jurisdiction of courts of a given state or triggering the instigation of the said proceedings in the courts of another member state which in lack of such manipulation would not be a competent body. Additionally, the action of the petitioner does not constitute taking advantage by him of the freedom in the internal market but is aimed exclusively at obtaining a private benefit connected with harming the defendant and generating high costs. The analysis of the case law includes all the cases in which CJ directly or indirectly in European civil procedural law referred to the so-called abuse of right. The CJ dealt with various abuses directly or indirectly taking the form of a widely defined abuse of right and they referred to both 'obtaining the jurisdictional grounds under false pretenses' as well as 'torpedo actions'. In this regard, the following cases should be mentioned: Mainschiffahrts-Genossenschaft eG (MSG) v. Les Gravières Rhénanes SARL. ${ }^{124}$

124 Judgement of CJEU dated 20 February1997, C-106/95, Mainschiffahrts-Genossenschaft eG (MSG) v. Les Gravières Rhénanes SARL, EU:C:1997:70. Comments on the decision see: K Weitz, 'Autonomiczna wykładnia europejskiego prawa procesowego cywilnego - wprowadzenie i wyrok ETS z 20.02.1997 r. w sprawie C-106/95 Mainschiffahrts-Genossenschaft eG (MSG) przeciwko Les Gravières Rhénanes SARL' (2008) 8 Europejski Przegląd Sądowy 54-57; N Watté, 'La désignation du lieu du for et du lieu d'exécution de l'obligation' [1998] Revue de droit commercial belge 380-382; J Van Haersolte, J Van Hof, 'Forumkeuze of plaats van uitvoering?' [1997] Nederlands tijdschrift voor Europees recht 79-80; A Rodríguez Benot, Revista española de Derecho Internacional (1997) 211-215; P Wautelet, The Columbia Journal of European Law (1997) 465473; ME Koppenol-Laforce, 'Forumkeuze; internationale handel, gebruik, het niet-bestaan van de overeenkomst' [1998] Nederlands tijdschrift voor burgerlijk recht 50-51; P Huber, Zeitschrift für Zivilprozess International (1997) 168-181; I Queirolo, 'La forma degli accordi sul foro nella Convenzione di Bruxelles del 1968: una recente pronuncia della Corte di giustizia’ [1997] Rivista di diritto internazionale privato e processuale 601-614; P Volken, Schweizerische Zeitschrift für internationales und europäisches Recht (1998) 128-129; R Foglia, A Saggio, 'Forma delle clausole attributive della competenza' [1997] Il Corriere giuridico 463-465; C Mereu, Journal des tribunaux (1997) 408-409; P Vlas, 'The EEC Convention on jurisdiction and judgments. Article 17: Jurisdiction clauses' (1999) Netherlands International Law Review 100-102; P Vlas, 'Art. 17 EEX - 'abstracte' aanwijzing van de plaats van uitvoering - mondeling overeengekomen forumkeuze - gebruik in de internationale handel' [1997] TVVS ondernemingsrecht en rechtspersonen 223-224; TC Hartley, 'Article 17 of the Brussels Convention: Jurisdiction Agreements' [1997] European Law Review 360-363; S Kubis, 'Gerichtspflicht durch Schweigen? - Prorogation, Erfüllungsortsvereinbarung und internationale Handelsbräuche’ [1999] Praxis des internationalen Privat- und Verfahrensrechts 10-14; O Schlosser, Entscheidungen zum Wirtschaftsrecht (1997) 359-360; H Holl, Volker Recht der internationalen Wirtschaft (1997) 418-419; S Klauer, St. Galler Europarechtsbriefe (1997) 260-262; A Huet, Journal du droit international (1997) 625-634; J Maseda Rodríguez, 'Algunas consideraciones respecto de los artículos 5.1 y 17 del Convenio de Bruselas de 27 de septiembre de 1968. Comentario a la sentencia del TJCE de 20 de febrero de 1997’ (1997) 4296 La ley - Unión Europea 12-14; S Phillips, 'Abstract jurisdiction agreements and the Brussels Convention' (1998) International Trade Law Quarterly 57-60; H Tagaras, Cahiers de droit européen (1999) 190-201; ME Koppenol-Laforce, 'Plaats van uitvoering en rechterlijke bevoegdheid' [1998] Nederlands tijdschrift voor burgerlijk recht 45-48; P Schlosser, 'Rechtszersplitterung durch internationales Einheitsrecht?' in Festschrift fur Ulrich Magnus: zum 70. Geburtstag (SELP 1999) 543-554; H Gaudemet-Tallon, Revue critique de droit international privé (1997) 572-577; P Vlas, Nederlandse jurisprudentie; Uitspraken in burgerlijke en strafzaken (1998) 565. 
Réunion européenne SA and Others v. Spliethoff's Bevrachtingskantoor BV and the Master of the vessel Alblasgracht V002, ${ }^{125}$ as well as AS-Autoteile Service GmbH v. Pierre Malhé. ${ }^{126}$

Another issue of limits of unfair application or abuse of grounds for jurisdiction was indirectly touched upon in the decision of Athanasios Kalfelis v. Bankhaus Schröder, Münchmeyer, Hengst and Co. and others ${ }^{127}$, Freeport plc v. Olle Arnoldsson ${ }^{128}$, Reisch

125 Judgment of CJEU dated 27 October1998, C-51/97, Réunion européenne SA and Others v. Spliethoff's Bevrachtingskantoor BV and the Master of the vessel Alblasgracht V002, EU:C:1998:509. Compare: RA Borrás, 'Jurisprudencia del Tribunal de Justicia de las Comunidades Europeas' [1999] Revista Jurídica de Catalunya 907-910; M Eslava Rodríguez, 'Interpretación por el TJCE de los arts. 5, aps. 1 y 3 y 6, ap. 1 del CB’ [2000] Anuario español de derecho internacional privado 810-812; A Font I Segura, 'La responsabilidad del porteador efectivo en el Convenio de Bruselas de 1968 (STJCE de 27 de octubre de 1998, as. C-51/97, Réunion Européenne SA y otros C. Spliethoff's Bevrachtingskantoor BV, Capitaine Commandant el navire "Alblasgracht V002")' [1999] Revista de Derecho Comunitario Europeo 187-207; P Delebecque, 'Condamnation de la théorie des groupes de contrats par la Cour de Justice des Communautés Européennes' [1999] Le droit maritime français 3334; S Klauer, 'Gerichtsstand für Klage aus Delikt und Vertrag bei mehreren Beklagten' [1999] European Law Reporter 142-144; P Volken, „Schweizerische Zeitschrift für internationales und europäisches Recht" 1999, pp. 450-451; A Briggs, 'Claims Against Sea Carriers and the Brussels Convention' [1999] Lloyd's Maritime and Commercial Law Quarterly 333-337; J Bauerreis, 'Le rôle de l'action directe contractuelle dans les chaînes internationales de contrats. Le rétablissement de léquilibre pécuniaire entre les maillons extrêmes d'une chaîne de contrats: l'action directe contractuelle exercée par le sousacquéreur à lencontre du vendeur initial de la chose non-conforme. La Convention de Bruxelles de 27 septembre 1968 et la désignation du tribunal internationalement compétent' [2000] Revue critique de droit international privé 341-348; H Koch, 'Europäische Vertrags- und Deliktsgerichtsstände für Seetransportschäden ("Weiche Birnen")' [2000] Praxis des internationalen Privat- und Verfahrensrechts 186-188; H Gaudemet-Tallon, „Revue critique de droit international privé” 1999, pp. 333-340; TC Hartley, 'Carriage of goods and the Brussels Jurisdiction and Judgments Convention' [2000] European Law Review 89-93; F Leclerc, 'Chronique de jurisprudence du Tribunal et de la Cour de justice des Communautés européennes' [1999] Journal du droit international 625-635; P Lombardi, 'Brevi note sulla più recente giurisprudenza comunitaria relativa alla Convenzione di Bruxelles del 1968: il caso Réunion européenne e il caso Van Uden' [1999] Contratto e impresa/Europa 455-468; A Crespo Hernández, 'Delimitación entre materia contractual y extracontractual en el Convenio de Bruselas: Implicaciones en orden a la determinación de la competencia judicial internacional. Comentario a la sentencia del TJCE de 27 de octubre de 1998' (1998) 4681 La ley - Unión Europeal-3.

126 Judgment dated July 1985, C-220/84, AS-Autoteile Service GmbH v. Pierre Malhé, EU:C:1985:302. More information in: R Geimer, 'EuGVÜ und Aufrechnung: keine Erweiterung der internationalen Entscheidungszuständigkeit - Aufrechnungsverbot bei Abweisung der Klage wegen internationaler Unzuständigkeit' [1986] Praxis des internationalen Privat- und Verfahrensrechts 208-216; E. Mezger, „Revue critique de droit international privé" 1986, pp. 147-153; TC Hartley, 'Costs and Counterclaims' [1986] European Law Review 98-99.

127 CJEU's judgment dated 27 September 1988, C-189/87, Athanasios Kalfelis v. Bankhaus Schröder, Münchmeyer, Hengst and Co. and others, EU:C:1988:45. See: R Geimer, 'Streitgenossenzuständigkeit und forum delicti commissi' [1988] Neue juristische Wochenschrift 3089-3090; FJ Jiménez Fortea, 'Comentario a la sentencia del Tribunal de Justicia de las Comunidades Europeas de 27 de septiembre de 1988 (artículos 5 y 6 del Convenio de Bruselas)' [1989] Revista General de Derecho 3939-3955; P Gottwald, 'Europäische Gerichtspflichtigkeit kraft Sachzusammenhangs' [1989] Praxis des internationalen Privat- und Verfahrensrechts 272-274; RA Borrás, 'Jurisprudencia del Tribunal de Justicia de las Comunidades Europeas' [1989] Revista Jurídica de Catalunya 538-540; TC Hartley, 'Jurisdictional Issues under Articles 5(1), 5(3) and 6(1)' [1989] European Law Review 172-175; R Ebbink, 'A Fire-Side Chat On Cross-Border Issues (before the ECJ in GAT v. LuK)' in D Beier, L Petit, C Heath (eds), Festschrift für Jochen Pagenberg (Heymann 2006) 255-262; E Ullmann, 'Die Verwarnung aus Schutzrechten - mehr als eine Meinungsäußerung?' [2001] GRUR 1027-1032; AV Gill, 'Multiple Defendants, Jurisdiction in Tort and the Brussels Convention' [1989] Irish Law Times and Solicitors' Journal 2-4; P Schlosser, 'EuGÜbk: Zuständigkeit bei mehreren Beklagten an verschiedenen Wohnsitzen - Begriff der unerlaubten Handlung' [1998] Recht der internationalen Wirtschaft 987-989; Huet (n 83) 457-461; H. Gaudemet-Tallon, 'Communautés européennes' [1989] Revue critique de droit international privé117-123; B Audit, 'Droit international privé [1989] Recueil Dalloz Sirey 254-255.

128 As in the judgment dated 11 October 2007, Freeport plc. 
Montage AG v. Kiesel Baumaschinen Handels GmbH. ${ }^{129}$ The same approach was continued in the subsequent decisions of CJ, in particular in the case of Eva-Maria Painer v. Standard VerlagsGmbH, Axel Springer AG, Süddeutsche Zeitung GmbH, Spiegel-Verlag Rudolf Augstein GmbH \& Co KG, Verlag M. DuMont Schauberg Expedition der Kölnischen Zeitung GmbH \& Co KG ${ }^{130}$ oraz Solvay SA v. Honeywell Fluorine Products Europe BV et al. ${ }^{131}$

129 CJ's judgment (second chamber) dated 13 July 2006, C-103/05, Reisch Montage AG v. Kiesel Baumaschinen Handels GmbH, EU:C:2006:471. More information in: M Barba, 'Leçon 1: De la connexité et de son instrumentalisation' (2016) 111 Revue Lamy droit des affaires 28-32; E Pataut, „Revue critique de droit international privé" 2007, pp. 181-186; L Idot, 'Règlement no 44/2001, "Bruxelles I"” (2006) 11 No 345 Europe 36; M Jánošíková, 'Osobitná právomoc a neprípustnost žaloby' [2009] Výber z rozhodnutí Súdneho dvora Európskych spoločenstiev 41-43; Ch Althammer, 'Die Anforderungen an die "Ankerklage" am forum connexitatis (Art. 6 Nr. 1 EuGVVO)' [2006] Praxis des internationalen Privat- und Verfahrensrechts 558-563; A Wittwer, 'Das EuGVO-Debüt des EuGH - Strittiges zur Streitgenossenschaft von insolventem Hauptschuldner und seinem Bürgen' [2006] European Law Reporter 424-425; M Würdinger, „Zeitschrift für Zivilprozeß International” 2006/11, pp. 180-190.

130 CJEU's judgement dated 1 December2011, C-145/10, Eva-Maria Painer v. Standard VerlagsGmbH, Axel Springer AG, Süddeutsche Zeitung GmbH, Spiegel-Verlag Rudolf Augstein GmbH \& Co KG, Verlag M. DuMont Schauberg Expedition der Kölnischen Zeitung GmbH \& Co KG, EU:C:2011:798. Compare: HP Roth, ,Urheberrecht: Schutz von Portraitfotografien' [2012] Europäische Zeitschrift für Wirtschaftsrecht 189-190; Ch Handig, ,EuGH zum Werkbegriff und zu den freien Werknutzungen' [2012] Ecolex 5860; N Lund, ,Verschwommene Konturen: Das Luxemburger Porträt der Konnexität des Art. 6 Nr. 1 EuGVVO' [2012] Recht der internationalen Wirtschaft 377-380; M Walter, Porträtfotos - Phantombild ${ }^{`}$ [2012] Medien und Recht 81-84; S Büttler, ,Urheberrechtsschutz von Porträtfotografien, insbesondere bei der Verwendung als Fahndungsbild' [2012] European Law Reporter 84-86; V Dahan, Ch Bouffier, 'Arrêt Painer du ler décembre 2011: la CJUE poursuit son oeuvre d'harmonisation du droit d'auteur' (2012) 80 Droit de l'immatériel: informatique, médias, communication 14-18; A Lucas, 'Droit d’auteur et droits voisins - Exceptions - Citation - Utilisation à des fins de sécurité publique' (2012) 42 Propriétés intellectuelles 30-31; P Sirinelli, 'Jurisprudence de la Cour de justice de l'Union Européenne. Accès à la protection' (2012) 232 Revue internationale du droit d’auteur 325-476; J Daleau, 'Enquête criminelle: reproduction de la photographie d'un portrait' (2011) Recueil Le Dalloz 2930; N Martial-Braz, 'Cliché d'une harmonisation du droit d'auteur par la CJUE: du grand art!' [2012] Recueil Le Dalloz 471-474; L Costes, 'Utilisation d'une photographie de portrait comme modèle pour établir un portrait-robot: l'analyse de la CJUE' (2012) 78 Droit de l'immatériel: informatique, médias, communication 14-15; B Michaux, 'La notion doriginalité en droit d'auteur: une harmonisation communatuaire en marche accélérée' (2012) Revue de droit commercial belge 599-601; VL Benabou, 'Arrêt "Painer": la protection par le droit d'auteur d'une phototgraphie de portrait utilisée à des fins de recherche d'une personne disparue' (2012) 189 Journal des tribunaux/droit européen 146-148; L Idot, 'Compétence en cas de pluralité de défendeurs' (2012) 02 Europe 45-46; L Idot, 'Droit d’auteur et photographies' (2012) 02 Europe 37-38; M.M Van Eechoud, „AMI: Tijdschrift voor auteurs-, media \& informatierecht” 2012, pp. 73-75; MR De Zwaan, 'Ruimte in het citaatrecht in Europa? Zoekmachine vindt niets bij "search naar flexibility"' [2012] AMI: Tijdschrift voor auteurs-, media \& informatierecht 141-148; ThM De Boer, „Nederlandse jurisprudentie; Uitspraken in burgerlijke en strafzaken” 2013/66; S.J. Schaafsma, „Intellectuele eigendom \& Reclamerecht” 2012, pp. 155-158; P.B. Hugenholtz, „Nederlandse jurisprudentie; Uitspraken in burgerlijke en strafzaken” 2013/66; V. Rörsch, „Mediaforum: Tijdschrift voor Media- en Communicatierecht” 2012, pp. 106-107; P.G.F.A. Geerts, „Intellectuele eigendom \& Reclamerecht" 2012, pp. 158-162; C Oro Martinez, 'Tribunal de Justicia: Espacio de libertad, seguridad y justicia - Competencia judicial internacional - Sentencia del Tribunal de Justicia de la Unión Europea (Sala Tercera), de 1 de diciembre de 2011, asunto C-145/10, Eva-Maria Painer c. Standard VerlangsGmbH y otros', (2012) 2 Revista española de Derecho Internacional 218-220; Z Skubic, 'Ali se portretna fotografija ugrabljene deklice šteje za umetniško delo?' (2011) 48 Pravna praksa 23; CE. Mezzetti, 'Il caso Painer: una rivoluzione copernicana per la tutela della fotografia in Italia?' [2012] Giurisprudenza italiana 2563-2569; M Dimattia, 'Cronaca giudiziaria e diritti d’autore sullopera fotografica di fronte alla Corte di giustizia' [2012] Il diritto dell'informazione e dell'informatica 212-219.

131 CJEU'S judgement (third chamber) dated 12 July 2012, C-616/10, Solvay SA v. Honeywell Fluorine Products Europe BV et al., EU:C:2012:445. See: Th.M. De Boer, „Nederlandse jurisprudentie; Uitspraken in burgerlijke en strafzaken” 2013/67; S.J. Schaafsma, „Intellectuele eigendom \& Reclamerecht" 2012, pp. 530-532; PLC. Torremans, 'Artikel 6, 1. Brussel I: onveranderde tekst maar geen duidelijke weg voorwaarts' [2013] Revue de droit commercial belge 431-440; CJJC Van Nispen, "Het doek weer opgetrokken voor de "dutch cross border injunction"" [2012] Berichten industriële eigendom 263-265; Ch Gielen, „Nederlandse jurisprudentie; Uitspraken in burgerlijke en strafzaken” 
Here we cannot ignore the influence of protraction of the proceedings in the action which was initiated as the first one on the obligation to respect the general lis pendens in the context of regulation no. 44/2001. In the decision concerning the case of Erich Gasser $G m b H v$. MISAT Srl, ${ }^{132}$ the CJ expressed the opinion that it is not permissible to refrain from applying Art. 21 of the Brussels convention, which analogously must be applied to Art. 27 of the regulation No. 44/2001. When issuing the decision the CJ took a stance that the time priority principle shall apply even if the first action was initiated with a breach of the contract granting exclusive jurisdiction in a given case to courts of a different member state. The literature contains conflicting views though: in accordance with the first one this issue is presented as the clear rejection of the concept of abuse of procedural right. According to the second view, CJ in fact showed that two independent issues were touched upon in this case: interpretation of Art. 21 of the Regulation No. 44/2001 and abuse of procedural right. The CJ interpreted Art. 21 of Regulation No. 44/2001 and refrained from commenting on the second issue. It can be assumed that $\mathrm{CJ}$ did not reject the concept of civil procedural law but only refused to solve this problem. ${ }^{133}$ What is more, it is suggested that $\mathrm{CJ}$ unintentionally led to the development of the tactic of malus forum shopping. ${ }^{134}$

Taking into account Regulation No. 1215/2012 the discussion about abuse of procedural right is at an early stage. ${ }^{135}$ One of the purposes of European legislator, while revising the regulation no. $44 / 2001$, is to solve this problem and eliminate abuses. ${ }^{136}$

2013/67; B Sujecki, 'Die Solvay-Entscheidung des EuGH und ihre Auswirkungen auf Verfahren über Immaterialgüterrechte’ [2013] Gewerblicher Rechtsschutz und Urheberrecht INT 201-214; H Schacht, 'Neues zum internationalen Gerichtsstand der Streitgenossen bei Patentverletzungen' [2012] Gewerblicher Rechtsschutz und Urheberrecht INT 1110-1113; S Dack, 'Solvay/Honeywell a sleeping beauty' [2013] Willem Hoyng Litigator 357-382; S Dack, 'Solvay/Honeywell - a sleeping beauty' [2013] Berichten industriële eigendom 364-371; L Idot, 'Pluralité de défendeurs, demandes de mesures provisoires et compétences spéciales en matière de brevets' (2012) 10 Europe 50-51; E Treppoz, 'Compétence internationale en matière de contrefaçon de brevet européen' [2013] Revue critique de droit international privé 479-487; J Dolžan, 'Pristojnost nacionalnega sodišča v čezmejnem sporu zaradi kršitve evropskega patenta' (2012) 33 Pravna praksa 28; PA De Miguel Asensio, 'Jurisprudencia española y comunitaria de Derecho internacional privado - Tribunal de Justicia: Espacio de libertad, seguridad y justicia - Competencia judicial internacional - Competencia judicial en materia de violación de un derecho de patente europea [...] Sentencia del Tribunal de Justicia de la Unión Europea de 12 de julio de 2012, asunto C-616/10, Solvay SA y Honeywell Fluorine Products Europe BV et al' [2013] 65 Revista española de Derecho Internacional 200-203; PA De Miguel Asensio, '[Competencia judicial internacional] - Posibilidad de ejercitar acciones relativas a la infracción de derechos de propiedad industrial de varios estados ante un mismo tribunal - Tribunal de Justicia, Sala Tercera, Sentencia de 12 de julio de 2012, asunto C-616/10 [Solvay SA/Honeywell Fluorine Products Europe BV e.a.]' (2012) XII Anuario español de derecho internacional privado 835-840; F Ferrari, 'La Corte di giustizia e il foro dei provvedimenti cautelari inibitori in materia di proprietà industriale' [2012] Int'l Lis 117-126.

132 Judgment dated 9 December 2003, C-116/02, Erich Gasser GmbH v. MISAT Srl, EU:C:2003:657. In the literature this judgment is described by P Grzegorczyk, P Rylski, K Weitz, 'Przegląd orzecznictwa Europejskiego Trybunału Sprawiedliwości z zakresu europejskiego prawa procesowego cywilnego (2003-2008)' (2009) 3 Kwartalnik Prawa Prywatnego 811-814. See also R Fentiman, 'Case C-116/02, Erich Gasser GmbH v. MISAT Srl')' (2005) 42 (No1) Common Market Law Review 241-259.

133 Compare Klöpfer (n 8) 183 and the literature quoted there.

134 R Fentiman, Art 31 in U. Magnus, P. Mankowski (eds), European Comentaries on Private Internation Law. Commentary, Brussels I bis Regulation (Köln 2016) 750; R Fentiman, 'Jurisdiction Agreements and Forum Shopping in Europe' [2006] Butterworth's Journal of International Banking and Financial Law 304; J Mance, 'Exclusive Jurisdiction Agreements and European Ideals' (2004) 120 LQR 2004/120 357 et seq.

135 See compare Klöpfer (n 8).

136 B Hess, T Pfeiffer, P. Schlosser, Report on the application of regulation Brussels I in the member states, Heidelberg 2007; A Dickinson, 'Surveying the proposed Brussels I bis regulation: solid foundations but renovation needed' in A Bonomi, GP Romano (eds), Yearbook of private international law (vol XII, München 2010) 247-310; U Magnus, 'Choice of court agreements in the review proposal for the 
There is a question whether the current regulation of the Regulation 1215/2012 eliminates the problem of abuse of European civil procedural right? ${ }^{137}$ Undoubtedly the system of respecting litis alibi pendentis was upheld in regulation No. $1215 / 2012,{ }^{138}$ however in a slightly changed form. In the light of Art. 29(1) of Regulation No. 1215/2012, not breaching Art. 31(2) if before the courts of different member states actions are instigated for the same claim between the same courts, the court in which the action was instigated later shall ex officio suspend the proceedings till the jurisdiction is established of the court where the first action was instigated. In cases defined in Subs. 1, at the request of the court before which the dispute is pending, every other court in which the action was instigated, shall forthwith inform the first court when the action was instigated in it pursuant to Art. 32 (Art. 29(2) of the Regulation No. 1215/2012). If the jurisdiction of the court in which the action was instigated as the first one was established, the court in which the action was instigated later shall find lack of jurisdiction, as the first court has it (Art. 29(3) Regulation No. 1215/2012). If before courts of different member states actions are initiated which are related to each other, each court in which the action was initiated later may suspend the proceedings (Art. 30(1) of Regulation No. 1215/2012). If such actions are instituted in the first instance court, each court in which the action was instituted later may at the request of the party find that it has no jurisdiction if the court in which the action was instigated as the first one has jurisdiction over the cases and combination of cases is compliant with its law (Art. 30(2) of Regulation no. 1215/2012). As interpreted in this article, it is believed that such cases are related to each other if the bond between them is so close that it is advisable to hear them and settle them jointly in order to avoid the issuance of conflicting decisions in separate proceedings (Art. 30(3) of Regulation No. 1215/2012). Provision of Art. 31 of Regulation No. 1215/2012 introduces a new measure aimed at protecting jurisdictional clauses through ${ }^{139}$ the obligation to deviate from the principle of time priority if the issue concerns respecting the jurisdictional contract containing the establishment of exclusive jurisdiction. ${ }^{140}$ This regulation exists in order to

Brussels I regulation' in E Lein (ed), The Brussels I review proposal uncovered (London 2012) 83-102; A Nuyts, Study on Residual jurisdiction - General report, September 2007.

137 Gajda - Roszczynialska (n 34)490 - 620.

138 More information in: R Fentiman, 'Art. 29, Art. 30' in U Magnus, P Mankowski (eds), European Comentaries on Private Internation Law. Commentary, Brussels I bis Regulation (Köln 2016) 713-748; S Leibe, 'Art. 29, Art. 30' in T Rauscher (ed), Europäisches Zivilprozess- und Kollisionsrecht, Brussel Ia - VO(Köln 2016) 866-895; K Weitz, 'Projektowane zmiany rozporządzenia $\mathrm{nr}$ 44/2001' in P Grzegorczyk, K Weitz (eds), Europejskie prawo procesowe cywilne i kolizyjne (Warszawa 2012) 62 et seq.; P Rodziewicz, 'Art. 29, Art. 30' in J Gołaczyński (ed), Jurysdykcja, uznawanie orzeczeń sądowych oraz ich wykonywanie w sprawach cywilnych $i$ handlowych. Rozporzadzenie Parlamentu Europejskiego $i$ Rady (UE) nr 1215/2012. Komentarz (Warszawa 2015) 147-151.

139 See point 22 of the preamble where it was found that: "however, in order to enhance the effectiveness of contracts establishing exclusive jurisdiction and avoiding dishonest tactics in court proceedings, the exception from a general regulation concerning the instigation of actions shall be provided for in order to satisfactorily solve a particular case in which parallel actions may be instigated. It is a situation in which the action was instigated in the court not indicated in the exclusive jurisdiction contract and then in the dispute concerning the same claim and between the same parties an action was instigated in the court indicated in such a contract. In such a case the court in which the action was instigated as the first one shall suspend the proceedings when the action is instigated in the court indicated in the contract and till the said court finds that it has no jurisdiction pursuant to the exclusive jurisdiction contract. It is to guarantee that in this situation the court indicated in the contract has priority of deciding on the validity of the contract and the scope in which this contract applies to the dispute it is to hear. The court indicated in the contract shall be able to conduct the proceedings irrespective of the fact whether the court not indicated in the contract already decided to suspend the proceedings'.

140 See I Bergson, 'The death of the torpedo action? The practical operation of the Recast's reforms to enhance the protection for exclusive jurisdiction agreements within the European Union' (2015) 11 JPIL 6 et seq. 
introduce an exception from lis pendens, doctrine if the actions pending are parallel in the court assigned in the jurisdictional contract and the court of another country than the country indicated in the jurisdictional clause. In this situation the priority is held by the court indicated in jurisdictional contract as pursuant to Art. 31(2) of Regulation No. 1215/2012, without breaching the provisions of Art. 26, if the action is instigated in the court of the member state which in the contract defined in Art. 25 was stated as having exclusive jurisdiction, every court of another member state shall suspend the proceedings till the court indicated in the contract does not find that it has no jurisdiction under such a contract. Also pursuant to Art. 31(2) of Regulation No. $1215 / 2012$, if the court indicated in the contract found that is has jurisdiction pursuant to the contract, every court of another member state shall find that it has no jurisdiction to the benefit of this court. The newly introduced measure without any doubts offers the required protection in the scope of jurisdictional contracts as per the choice of the competent court in many situations occurring in case of parallel proceedings. ${ }^{141}$ However, it is doubtful whether definitely the problem of abuse of procedural right is eliminated under Regulation No. 1215/2012. ${ }^{142}$

141 See with respect to the role of jurisdiction contracts in Brussels I bis system: J Basedow, 'Exclusive choice-of-court agreements as a derogation from imperative norms' in P Lindskoug, U Manusbach, G Millqvist (eds), Essays in honour of Michael Bogdan (Lund 2013) 15-31; P Durand-Barthez, 'The "governing law" clause: legal and economic consequences of the choice of law in international contracts' (2012) 5 International Business Law Journal/Revue de Droit des Affaires Internationales 505-518; P Garcimartin, 'Prorogation of jurisdiction' in A Dickinson, E Lein (eds), The Brussels I regulation recast (Oxford 2015) 25-26; XE Kramer, 'Competitie in de Europese civiele rechtsruimte: een spanningsveld in de grensoverschrijdende geschillenbeslechting?' (2014/51) 4 Tijdschrift voor Privaatrecht 17451806; PA Nielsen, 'The new Brussels I regulation' (2013/50) 2 Common Market Law Review 503-528; M Pertegás, 'Feeling the heat of disputes and ending the shade of forum selection' [2015] Nederlands Internationaal Privaatrecht374-375; SI Strong, 'Limits of procedural choice of law' (2014) 39 Brooklyn Journal of International Law 1027-1121.

142 See Gajda - Roszczynialska (n 34) 490- 620; K Hilbig-Lugani, 'Der gerichtsstandsvereinbarungswidrige Torpedo - wird endlich alles gut? Ein Beitrag zur EuGVVO 1215/2012' in R Geimer, A Kaissis, RC Thümme (eds), Ars aequi et boni in mundo: Festschrift für Rolf A. Schütze zum 80. Geburtstag (München 2015) 195204; Coester-Waltjen (n 115) 22; Ch Heinze, 'Choice of Court Agreements, Coordination of Proceedings and Provisional Measures in the Reform of the Brussels I Regulation' (2011/75) 3 Rabels Zeitschrift für auslaendisches und internationales Privatrecht" 2011/75 581-618; G Cuniberti, 'Lis Pendens and Jurisdiction Clauses' in B Hess, M Bergstrom, E Storskrubb (eds), EU Civil Justice. Current Issues and Future Outlook: Swedish Studies in European Law (vol 7, Oxford-Portland, Oregon 2016) 25-27; Bergson (n 141) 1-30; PA Nielsen, 'The End of Torpedo Actions?' in Cross-border Litigation in Europe: the Brussels I Recast Regulation as a Panacea? (ed F Ferrari, F Ragno Francesca, Studi e pubblizzioni della Rivista di diritto internazionale privato e processuale 2016) pp 153-169; PA Nielsen, 'Current Developments. The Recast Brussels I Regulation' (2014/83) 1 Nordic Journal of International Law 61-71; PA Nielsen, 'Current Developments. The State of Play of the Recast of the Brussels I Regulation' (2012) 81 (4) Nordic Journal of International Law 585-603; M Herranz Ballesteros, 'The regime party autonomy in the Brussels I recast: The solutions adopted for agreements on jurisdiction' (2014/10) 2 Jurisdiction of private International Law 291-308; T Ratkovic, D Zgrabljić Rotar, 'Choice-of-Court agreements under the Brussels I Regulation (Recast)' (2013) 9 Journal of Private International Law 245-268; D Kenny, R Hennigan, 'Choice-of-Court Agreements, the Italian Torpedo, and the Recast of the Brussels I Regulation' (2015) 64 ICLQ 197-210; FM Wilke, 'The impact of the Brussels I Recast on important "Brussels" case law' (2015) 11 (1) Journal of Private International Law128-142; Q Forner-Delaygua, 'Changes to jurisdiction based on exclusive jurisdiction agreements under the Brussels I Regulation Recast' (2015) 11 (3) Journal of Private International Law 379-405; Ch Heinze, B Steinrötter, 'The Revised Lis Pendens Rules in the Brussels I bis Regulation' in V Lazic, S Stuij (eds), Brussels I bis Regulation: Changes and Challenges of the Renewed Procedural Scheme (The Hague 2017) 1-26; XE. Kramer, E Themeli, 'The Party Autonomy Paradigm: European and Global Developments on Choice of Forum' in: V Lazic, S Stuij (eds), Brussels I bis Regulation: Changes and Challenges of the Renewed Procedural Scheme (The Hague 2017) 27-49; T Domej, 'Die Neufassung der EuGVVO - Quantensprünge im europäischen Zivilprozessrecht' (2014) 78 Rabels Zeitschrift für ausländisches und internationales Privatrecht 533-537; M Pohl, 'Die Neufassung der EuGVVO - im Spannungsfeld zwischen Vertrauen und Kontrolle' (2013) 2 109-114; M Wagner, 'Aktuelle 
It seems that the solutions adopted in Art. 29 and Art. 31(2) of Regulation No. 1215/2012 do not eliminate fully the risk of the so-called Italian torpedo and forum running. It is because it refers only to jurisdictional contracts granting exclusive jurisdiction to hear a given case to a court selected by the parties. ${ }^{143}$ Doubts and the risk of abuse arise in case of contracts indicating more than one jurisdiction. The so-called Italian torpedo is still possible in case of disputes arising from contractual relations where the parties did not agree on jurisdiction. What is more, it is still possible in case of prohibited acts and in every case in which the regulations allows for alternative possibility of selecting jurisdiction criteria. ${ }^{144}$

The risk of abuse of procedural right still exists in particular in case of concluding contracts indicating more than one jurisdiction and existence of a few conflicting jurisdictional clauses in them. In such a case the mechanism under Art. 31 of Regulation No. 1215/2012 is excluded. It is clear that the mechanism introduced by Art.31(2) and Art. 31(3) of Regulation No. 1215/2012 is designed to operate only if there is only one clause concerning the exclusive jurisdiction and does not apply in cases in which more then one clause may apply. ${ }^{145}$ Doubts will arise in case of hybrid or asymmetric clauses. It is possible that in case of extended contractual relations the claims of the parties will be included in the scope of not one, but a few jurisdictional clauses which may provide for jurisdiction of different courts. In such a situation conflicting jurisdictional clauses existing in the main and special contract will lead to parallelly instigated actions in courts of different countries. Due to the fact that point 22 of the preamble of the Regulation No. 1215/2012 directly excludes the situation referring to conclusion of conflicting contracts establishing exclusive jurisdiction from the regulation including the said measure under Art. 31(2) of Regulation No. 1215/2012, the general lis pendens shall apply. In other words it means that the general rule concerning instigation of the action applies in the said situation if the parties concluded conflicting contracts establishing exclusive jurisdiction. ${ }^{146}$ Due to this fact it is necessary to contemplate the

Entwicklungen in der justiziellen Zusammenarbeit in Zivilsachen' [2012] NJW 1333; A Nuyts, 'La refonte du règlement Bruxelles I' (2013/102) 1 R.C.D.I.P. 42-59; P Wautelet, 'Clauses délection de for et procédures concurrentes. Les innovations du Règlement 1215/2012', (2015) 1 TVIP/RDIP 152-156; V Egea, 'La solution des conflits de procédures dans le Règlement Bruxelles I bis' in E. Guinchard (ed), Le nouveau Règlement Bruxelles I bis, (Bruxelles 2014) 154-158; H Gaudemet-Tallon, C Kessedijan, 'La refonte du règlement Bruxelles' [2013] RTD Eur. 446-447; MA Lupoi, 'La nuova disciplina della litispendenza e della connessione tra cause nel regolamento Ue n. 1215 del 2012' (2013) 67(4) Rivista trimestrale di diritto e procedura civile 1425-1440; TC Hartley, Civil Jurisdiction and Judgments in Europe. The Brussels I Regulation, the Lugano Convention, and the Hague Choice of Court Convention (Oxford 2017) 225 et seq.; T.C. Hartley, Choice-of-court Agreements under the European and International Instruments. The Revised Brussels I Regulation, the Lugano Convention, and the Hague Convention (Oxford 2013) 227-231. See also K Weitz, 'Między forum prorogatum, a forum non prorogatum - wzmocnienie skuteczności umowy jurysdykcyjnej w świetle rozporządzenia Bruksela I bis' (2014) 9 Palestra181-198; P Grzegorczyk, 'Nowy fundament europejskiego prawa procesowego cywilnego: jurysdykcja krajowa, zawisłość sprawy oraz uznawanie i wykonywanie orzeczeń w sprawach cywilnych i handlowych według rozporządzenia Rady i Parlamentu Europejskiego nr 1215/2012 (Bruksela Ia),cz. I' (2014) 6 Przegląd Sądowy13-17; B Trocha, 'Problematyka zawisłości sprawy w rozporządzeniu 1215/2012 (Bruksela I bis)' (2013) 20 Monitor Prawniczy 1074; J Puchała, 'Zawisłość spraw wszczętych przed sądami różnych państw członkowskich w świetle rozporządzenia nr 1215/2012’ (2016) 11 Europejski Przegląd Sądowy 12-13; Trocha (n 70) 223 et seq.

143 Hilbig-Lugani (n 143) 195-204.

144 Gajda - Roszczynialska (n 34) 490 - 620; G Bisello, C Cognetti, F Lo Gerfo, 'Deactivating the Italian Torpedo' (2015) International Judicial Cooperation in Civil Matters - European Civil procedure 18-19.

145 Gajda - Roszczynialska (n 34) 490- 620; Cuniberti, (n 143) 24.

146 Gajda - Roszczynialska (n 34) 490- 620; Cuniberti, (n 143) 25-27. 
need for defining the notion of conflicting jurisdictional clauses, in particular in the context of the notion of exclusive jurisdiction, as well defining the competent court for determination which of the conflicting clauses applies and thinking of a special evidence standard to determine the existence of conflicting jurisdictional clauses.

In the context of abuse of right doubts are raised by Regulation in Art. of the Regulation No. $1215 / 2012$ whether the provisions of which jurisdictions indicated by the parties shall decide on the validity of jurisdictional contract. Firstly, the issue of the so-called reverse torpedo arises. ${ }^{147}$ This results from the fact that regulation of Art. 31(2) of Regulation No. 1215/2012 is applicable only if the action is instigated in the court designated in the contract. The existence of jurisdictional contract per se is not enough to stop the proceedings in the competitive court, and the sense of the provision is up to date only if the action in the action in the court designated in the contract is instigated as the second action - otherwise for such a court the general time priority rule suffices to exercise jurisdiction. ${ }^{148}$ However, it means that tactically through using forum shopping it is possible to instigate initial proceedings before the preferred court, invoking the existence of jurisdictional contract in this court, indicating Art. 32(2) of Regulation No. 1215/2012, and to force the defendant to initiate defense. In practice, the risk of such reverse torpedo may be minimized depending on the national regulation; however, if there were cynical grounds for invoking jurisdiction under art. 25 of the Regulation, then such a step may be regarded as infringing the procedural law and penalized in the form of costs of the proceedings. ${ }^{149}$ It means however nonelimination of abuse of malus forum shopping. ${ }^{150}$

Pursuant to the wording of Art. 25 of Regulation No. 1215/2012, the validity of jurisdictional contract shall be assessed under the legal provisions of the court of the member state selected by parties in the contract. This regulation is confirmed also in point 20 of preamble to the Regulation. It means that the issue of existence of conflicting jurisdictional clauses should be analysed in the court in which the action was instigated as the first one. The logic of lis pendens principle consists in full trust, namely in designation of the court into which the case was filed as first, to determine its jurisdiction. ${ }^{151}$ As a consequence, it seems inevitable for the first court to assess the validity, and perform the full analysis of jurisdictional arguments of the parties as for existence of the main contract and special contracts and their provisions. It often means the necessity to hold evidence proceedings, which may make the proceedings lengthy. One of the ways to prevent such delay would be to impose a certain evidenciary standard for assessing the allegations concerning the existence of jurisdictional clause to achieve effect of lis pendens rule. Currently there are no such consolidated standards. The issue of compliance with national evidenciary standards with Brussells regime was decided by CJEU in its decision concerning the case of Shevill. ${ }^{152}$ It means that particular member

\footnotetext{
147 Fentiman (n 135) 751.

148 Weitz (n 143) 189-190; Trocha (n 70) 224.

149 Fentiman (n 135) 751.

150 Gajda - Roszczynialska (n 34) 490 - 620.

151 M Weller, 'Mutual trust: in search of the future of European Union private international law' (2015/11) 1 Journal of Private International Law' 64-102.

152 Judgment dated 7 March 1995, C-68/93, Fiona Shevill, Ixora Trading Inc., Chequepoint SARL and Chequepoint International Ltd v. Presse Alliance SA, EU:C:1995:61. See also the judgment of Kratzer, points 41, 42 and the case law quoted therein; the judgment of Vinyls Italia SpA, point 53.
} 
states will always have other standards concerning taking evidence, in particular for examining the allegations on existence of jurisdictional clause to achieve the effect of lis pendens rule. ${ }^{153}$

We should also consider whether the court indicated as the second one has to suspend the proceedings till decision is taken by the court in which the action was instigated as first. If only one exclusive jurisdiction exists, lis pendens rule under Art. 29(1) of the Regulation No. 1215/2012 orders to do so. It is debatable, however, if the suspension obligation exists also in situations in which existence of conflicting clauses is questioned. The court in which the action was initiated as the second one may in a different way perceive the existence of competing clauses granting jurisdiction than the court in which the action was started as the first one. There may be a specific situation in which the challenged clause may not exist and in reality there is only one jurisdictional clause, which makes the court in which the action was started as the second one, the only jurisdictionally selected court. From the perspective of the court in which the action was initiated as the second one, the case could be subject to mechanism ofArt. 31(2) of Regulation no. 1215/2012 and then the general rule of lis pendens would not apply. Taking into account the interpretation as for the purpose, the second court could take a stance that there are no grounds for waiting for the decision of the court in which the action initiated as the first one, as the purpose of using the measure under Art. 31(2) of Regulation no. 1215/2012 was exactly the protection of important jurisdictional clauses in such situations. The argument of conflicting clauses should be taken into account irrespective of the existence of a lower or higher evidentiary standard. This would result in the situation where implementation of the first procedure would not delay the procedure in the selected court, but on the other hand, a risk of conflicting decisions and breaching the mutual trust principle would be higher. ${ }^{154}$. Wherefore, the definitive statement that the threat of so-called Italian torpedo is eliminated is significantly exaggerated. ${ }^{155}$

In the context of the rule under Art. 29 of Regulation No. 1215/2012 a situation is possible in which there will be conflicting exclusive jurisdiction contracts with an assumption on the identity of subject matter and individuals. ${ }^{156}$ This may result in the fact that although claims can be related to each other, they may not have the same facts as grounds (especially if the facts are complicated) or legal basis (even in the scope of widely defined requirement for their identity) $)^{157}$ or even the so-called identity of purposes (the purpose of the action) suggested as peculiar remedy). ${ }^{158}$ For example, the parties may conclude the framework contract together with executive contracts. Those contracts may include various jurisdictional clauses which separately ensure that each dispute arising from the current framework contract and executive contract shall be settled by specific other courts. Substantive demands of the parties should be probably analysed as breaching substantive clauses of each of the contracts. However, if the jurisdictional clauses were formulated narrowly, they would include only claims

153 Gajda - Roszczynialska (n 34) 490 - 620.

154 However, see the decision of 'Tatry’. See also Weller (n 152) 64-102.

155 Gajda - Roszczynialska (n 34) 490-620; Cuniberti (n 143) 31.

156 With regard to identity as per subject matter concerning lis pendens see Trocha (n 70 ) 180 et seq. Zob. również S Leibe, 'Art. 31' in Europäisches Zivilprozess- und Kollisionsrecht 896-897.

157 See the judgement of 'Tatry', point 39.

158 See the judgement of 'Tatry', point 41. 
provided for in the contract to which they relate. Each of the party would have to rely on separate contacts both from the jurisdictional and substantive perspective. In this situation actions could often be based on separate contracts, and in consequence, relate to other procedural claims (of course assuming a specific concept of procedural claim) ${ }^{159}$ The issue of jurisdiction would have to be assessed in two stages. At the first stage the court should find what is the subject matter of each of the parallel proceedings, based on its own law to determine the subject of the process and on the foreign law with respect to the foreign process. At the second stage lex fori should be decisive. ${ }^{160}$ Although there is no clear decision of CJEU in this aspect, it should be supposed that there will not be identity as to the subject matter in case of claims only related to each other, and, as a consequence, they will not be subject to the general rule of lis pendens and the said measure may not be applicable. ${ }^{161}$

Another issue is whether application of the measure provided for by Art. 31(2) of Regulation No. 1215/201 will apply with respect to the so-called complex clauses, in particular asymmetric ones. It is possible to apply more complex clauses (contracts), and in particular asymmetric clauses (contracts) (so-called one-direction, unilateral ones). ${ }^{162}$ Those contracts (clauses) are common in certain branches, such as e.g. banking law. They are characterized by the fact that in an uneven, asymmetric way they shape the jurisdiction, in particular imposing on one party the obligation to submit the petition in one specific court (e.g. by the borrower) but they give numerous options to the other party (e.g. bank) which is then entitled to instigate the proceedings in various jurisdictions. ${ }^{163}$ Complex clauses, in particular such as asymmetric clauses, are connected with a number of problems in the context of lis pendens rule due to the doubts about the possibility of classifying asymmetric jurisdictional contracts as exclusive jurisdiction contracts. In such a case there is a question whether the measure under art. 31(2) of Regulation No. 1215/2012 is applicable to such asymmetric clauses. There are three approaches to this issue. ${ }^{164}$

According to the first view prorogation contract (or clause) including the establishment of exclusive jurisdiction assumes establishment of jurisdiction only of one specific court, and any other prorogation contract (or clause) granting jurisdiction to more than one court cannot be deemed exclusive. ${ }^{165}$ Such interpretation will result in an assumption that asymmetric jurisdictional contracts in any way cannot be treated as exclusive jurisdiction contracts. So Art. 31(2) of Regulation No. 1215/2012 is not applicable to jurisdiction contracts indicating more than one jurisdiction, then each time the general rule of lis pendens shall apply.

The second approach assumes that the assessment whether we deal with exclusive jurisdiction contract in case of asymmetric contracts (clauses) shall be defined from the perspective of each of the parties in isolation from others. Asymmetric contract has,

159 Cuniberti (n 143) 29; A Briggs, Agreements on Jurisdiction and Choice of Law (Oxford PILS) 285.

160 I Queirolo, 'Art. 27' in: U Magnus, P Mankowski (eds), European Comentaries on Private Internation Law. Commentary, Brussels I bis Regulation (Köln 2016) p 688-689.

161 the judgment in Gubisch case; the judgment in 'Tatry' case.

162 See Hartley (n 143) 241.

163 Fentiman (n 135) 752 and the literature quoted there,

164 The approaches are described in: Gajda - Roszczynialska (n 34) 490 - 620.

165 Cuniberti, (n 143) 30. 
so as to say, double character and may include, on the one hand, exclusive jurisdiction defining one exclusive court for each party and nonexclusive one, defining for the other party e.g. two courts. From this perspective the clause having jurisdiction of the 'court where to sue' may be exclusive although the court is different depending on who instigated the proceedings, of course subject to Art. 17 of Regulation No. 1215/2012 with respect to weaker parties. ${ }^{166}$

Third interpretation assumes that the meaning of the notion of exclusivity of jurisdictional contract consists only in the fact that prorogation contract excludes jurisdiction of some courts. From this point of view the number of courts which were granted jurisdiction in prorogation contract is not important, crucial is only that their jurisdiction excludes jurisdiction of other court(s) which would have jurisdiction. Applying this definition, asymmetric clauses could be also deemed exclusive clauses, including the clauses included in banking contracts for the bank. ${ }^{167}$

To sum up, depending on the assumed concept, if the jurisdictional clause (contract) is outside the scope of application of Art. 31(2) of Regulation No. 1215/2012, the general rule of lis pendens shall apply. However, in case of applying a new measure, all the nondesignated courts will have to suspend the proceedings till any of the designated courts in which the action was instigated dismisses the action and finds to have no jurisdiction over it. As a consequence, there may arise a problem of abuse of civil procedural right. ${ }^{168}$

Besides the said situations, grounds for establishing malus forum shopping still may have its source, for example in multiple meaning (vagueness) of notions used in the provisions on jurisdiction defining jurisdictional connecting factors, in multiplicity of jurisdictional grounds, which may happen e.g. in case of cumulation of general and special jurisdiction grounds (Art. 9-11, Art. 13 of Regulation No. 1215/2012), special regulation of forum non conveniens (Art. 12 of Regulation No. 1215/2012) or a more general exception from the norm included in Art. 8(1), namely Art. 12(3) of Regulation No. $1215 / 2012 .{ }^{169}$

\section{CONCLUDING REMARKS}

At the current stage of development there is no simple transposition of the issue of legal interest on the institution of abuse of procedural right; undeniably, the lack of current and real interest, with the assumption of fulfillment of other prerequisites, may be contemplated in categories of abuse of right by the court under ius dicere. In the Polish law it is not sufficient to analyse this phenomenon solely in the sphere of procedural locus standi and there must be the interest in taking a specific step. The lack of interest itself is not sufficient, as there must be the awareness of the party taking the step as to its inadmissibility and intention to harm the other party, as e.g. in case of fictitious actions. In the European area it is additionally necessary to create methodology and general approach to abuse of right in European civil proceedings and finding compromising

166 As in: Hartley, Choice-of-Court Agreements... (n 143) 141; Hartley, Civil Jurisdiction... (n 143) 241-242.

167 U Magnus in U Magnus, P Mankowski, Brussel I Regulation (Art. 23 (145-146) Munich 2011); R Geimer, R Schütze, 'Art 23 (166) Europäisches Zivilverfahrensrecht (2010).

168 Gajda - Roszczynialska (n 34) 490 - 620.

169 Gajda - Roszczynialska (n 34) 490 - 620. 
approach towards understanding of the notion of the interest in Roman and Germanic law systems. And because application and development of the law due to lack of procedural fairness and good faith is rather difficult to verify and to define, the advantage of adopting admissibility of a separate international institution of abuse of procedural right would lie in the possibility of applying a universal approach towards abuse of procedural right in all member states, which would mean that each court of the member state would apply the same standard of the test. Finally, the alternative use of exclusively national concepts of abuse of procedural right cannot be continued. It can be assumed that confirmation of the existence of the abuse of European procedural right in a given case would require existence of objective and subjective factors. Firstly, in terms of the objective factor, this requires so that the overall objective circumstances could indicate that despite formal respect for regulations provided for in European civil procedure regulations, the purpose of the procedural step resulting from a given procedural norm was not achieved. Secondly, such determination requires also a subjective factor, namely that overall objective factors would imply that the main purpose of a given procedural step was to gain unlawful benefit in a blatant way contradicting good practice to the detriment of the other party. 